University of Rhode Island

DigitalCommons@URI

Open Access Master's Theses

1972

\title{
The Role of an Old Woman: A Study of Edith Sitwell's Final \\ Persona
}

Stephen William Applin

University of Rhode Island

Follow this and additional works at: https://digitalcommons.uri.edu/theses

\section{Recommended Citation}

Applin, Stephen William, "The Role of an Old Woman: A Study of Edith Sitwell's Final Persona" (1972). Open Access Master's Theses. Paper 1371.

https://digitalcommons.uri.edu/theses/1371

This Thesis is brought to you for free and open access by DigitalCommons@URI. It has been accepted for inclusion in Open Access Master's Theses by an authorized administrator of DigitalCommons@URI. For more information, please contact digitalcommons-group@uri.edu. 


\section{THE ROLE OF AN OLD WOMAN: A STUDY OF EDITH SITWELI'S FINAL PERSONA}

\section{By}

STEPHEN WILIIAM APPLIN

A THESIS SUBMITTED IN PARTIAL FULFILLMENT OF THE REQUIREMENTS FOR THE DEGREE OF

MASTER OF ARTS

IN

ENGLISH

UNIVERS ITY OF RHODE ISLAND 


\section{MASTER OF ARTS THES IS \\ $\mathrm{OF}$}

STEPHEN WILIIAM APPLIN

Approved:

Thes is Committee:

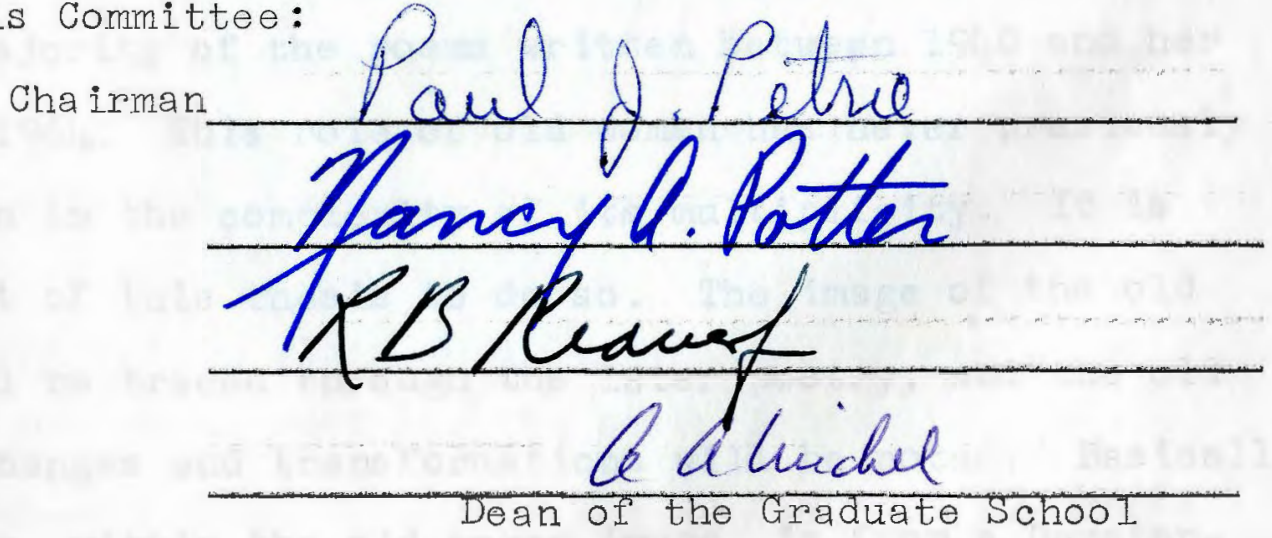

UNIVERSITY OF RHODE ISLAND

1972 


\section{THESIS ABSTRACT}

The year 1940 marked a radical change in the poetics of Dame Edith Sitwell (1887-1964). Previously the hallmark of her poetry had been her elaborate experimentation with the sounds of words. She regarded her experimentation as a revolt against Georgian insipidity. Her findings were radical and only slowly accepted by the poetry reading public. Her later poetry, however, has very little in common with the early. In 1940, Dame Edith was 53 years old. She was too old to continue finding pleasure through the sometimes shocking wit of her early experiments. She regarded herself as an old woman, and assumed the persona of an old woman in order that she might voice her beliefs through an image representative of her Self. The assumption of the role of the old woman is of primary importance to the later poetry, because it is this role that determines the point of view for the majority of the poens written between 1940 and her death in 1964. This role of old woman has never prefiously been shown in the complexity of its multiplicity. It is the object of this thes is to do so. The image of the old woman will be traced through the later poetry, and the old woman's changes and transformations will be noted. Basically the change, within the old woman image, is from a Demeterlike corn goddess to an individuated self, supplicating before Christ. Dame Edith's old woman relates herself to 
many Godheads and humans along the path towards Christianity, and almost all are representative of either love, rebirth or generation. It will be seen within the context of this thes is that Dame Edith agrees completely with Frazer, who states, "The sexual instinct has moulded the religious consciousness of our race."l The old woman participates in the reality of this quote. She is representative of everything generative. The later poetry is a series of identifications of the old woman with different Godheads and/or the natural phenomena which corresponds to an aspect of a Godhead. Through the writing of this poetry Dame Edith seems to be looking for a liberation from mortality. With few exceptions all the Gods and Goddesses are of the corn (including Christ in the eucharistic sense). Because the corn is reborn every jear, it is identified with rebirth. Dame Edith's later poetry is an expression of her yearning for rebirth. Frazer makes a not so subtle pun, when he calls this type of thinking "grasping at straws."2 Dame Edith has none of Frazer's objectivity. Her intention is to escape from mortality, and it sometimes seems as if her later poetry is a great optimistic rationalization meant to ease her cosmic anxiety. Most of the poetry discussed herein will be seen through the narrow vision of directed analyses. Therefore, allusions whether historical, biographical, Biblical or otherwise will sometimes be passed over for the sake of brevity.

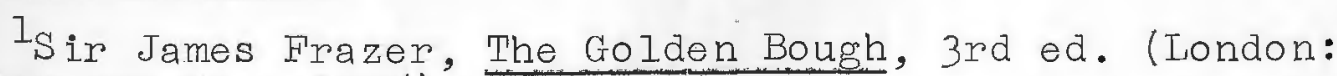
Macmillan and Co., 1925), VII, viili.

2 Ibid., VII, 91 . 
Chapter

ABS TRACT

I. INTRODUCTION. • • • . . . • • . • . .

Dame Edith's Later Poetry

Her Use of Symbolism

"The Poet Laments the Coming of Old Age" The 01d Woman as Demeter

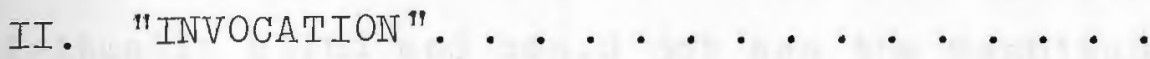

III. "AN OLD WOMAN" . . . . . . . . . . . .

...Part I

*.. "Harvest"

"A Mother to Her Dead Child"

IV. "EURYDICE" . . . . . . . . . . . . . . •

"Song For Two Voices"

"One Day in Spring"

"The Two Loves"

V. POEMS 1945-1949. . . . . . . . . . .

"The Bee Oracles"

"Mary Stuart to James Bothwe11"

"A Hymn to. Venus"

"The Canticle of the Rose"

VI. POEMS 1949-1954. . . . . . . . . . .

"Bagatelle"

"The Road to Thebes"

VII. POEMS 1954-1963. . . . . . . . . .

SELECTED BIBLIOGRAPHY . • • • • • • • • • • • • 


\section{INTRODUCTION}

The later poetry of Edith SitwelI (1887-1964) was begun after the outbreak of World War II. This large segment of her poetry can be seen as a distinct unit of cohesive material which is stylistically and thematically unified. In many ways the poetry can be seen as a direct reaction to the war. It appeared to Dame Edith that the world had become spiritualy blind and could not see the magnitude of its own atrocities. Dame Edith wrote the later poetry so that a larger, more spiritual sight might return to man. Her sight, her view of the world is the subject matter of the later poetry. She saw the war as the antithesis of generation. She, therefore, wrote of generation. Ultimately even war and destruction are incorporated into her view of a divinely controlied natural order, but neither actual vicious destruction nor the natural degeneration of herself will ever be viewed placidly or apathetically. Dame Edith viewed God and life as a great process of generation, and all things participated in this process. Generation and regeneration are at the core of her religious feelings, and the poetry she wrote at this time is certainly religious poetry. Dame Edith writes, "My poems are hymns of praise to the glory of Iife." I Ife is not a static quantity. Dame Edith views life as rebirth, transformation and change. Her poems

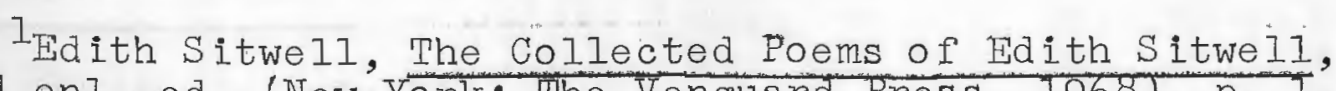
new and enl. ed. (New York: The Vanguard Press, 1968), p. I. 
celebrate the continuity of the earth's great generative history. They represent the generative history of the individual, or spring, of the earth. Generation equals creation, and it id Dame Edith's purpose to get to the heart of the mysteries of creative and generative life. To do this Dame Edith must leave the realms of substantial form, and seek the essence within the form. Essences are not eidetic; essences can only be translated symbolically. In the past, as now, the world's great religions have incorporated symbols, such as the wheat ear, to explain or exemplify the concept of rebirth. Within the context of this paper it would be helpful to consider religion, especially Dame Edith's religion, as perpetration, evolution and growth of a great complex of interrelated symbols.

Dame Edith explains her use of symbolism in "Some Notes On My Own Poetry."

Often a line can mean several things-all equally true. What $\mathrm{Mr}$. Lindsay says of the use of Lazarus as symbol is of the deepest truth. ("Lazarus is the poor man, the maker of bread who is also the living wheat, the murdered man round whom the forces of redemption most powerfully play.") I used the symbol thus. I used the symbol, also, as that of poverty, now moved into a new tomb of useless gold, in which, until the fires of love and spiritual rebirth reach him, he will lie as dead as in his tomb of mud... Lazarus the terrible ideal of useless suffering. Lazarus, the hero of death and mud, taking the place in men's minds of the Hero of Iife Who was born in a stable.2

As can be seen by this example, the symbolism of Edith

$$
{ }^{2} \text { Ibid., p. xiviii. }
$$


Sitwell is not the esoteric, excessively personal, selfindulgent symbolism of the egotist. Rather it is the universally acknowledged symbolism of western culture. It is the symbolism of known, and pre-tested quantities, which are not only the carriage of the religious mysteries she is presenting, but more emphatically, the symbolism lies at the heart of religious mystery itself. As we have seen in the example of Lazarus, religious mystery is a series of correspondences, connected by an alogical intuitive feeling for similarity and potential meaning. It is this correspondence of symbol to symbol which enlarges the consciousness of the reader. Faith and belief connect one symbol to another. This connection tells a truth that cannot be explained in any other way. As Lazarus is poor man/ baker/wheat/ and Christ, so is the sun: Christ/ Orpheus/Zeus/the Wanderer/ the Lost One/ and the impregnator of the earth. Likewise, the earth is the old woman/ Demeter/Persephone/ Eurydice/ the corn goddess/ the country Fate/ Dame Edith Sitwell and many more. The correspondent relationships of the old woman myth complex is the subject of this paper. Dame Edith describes the thought process behind this system of correspondences, when she writes,

Seeing the immense design of the world, one image of wonder mirrored by another image of wonder-the pattern of fern and of feather by the frost on the window-pane, the six rays of the snowflake mirrored in the rock-crystal's six rayed eternity--seeing the pattern on the scaly legs of birds mirrored in the pattern of the knot-grass, I asked myself, were those shapes molded by blindness? Are not these the 
'correspondences,' to quote a phrase of Swedenborg,

'whereby we may speak with angéls?'3

Dame Edith is speaking specifically of her earlier poetry, but the thought process of recognizing similarities in divergent elements is the same. The similarities which she saw in the perceptual world in her youth, she presents later in the abstraction of her symbolism.

The reason she turned from her early esoteric writings to these great images of the collective unconscious (a term used loosely) can only be seen under the dim light of speculation. Previous to 1940 , she had abstained from writing poetry for a Imost ten years. In 1940, the war had begun. The war might be considered the primal impulse of the later poetry. It is always in the later poetry, in the form of the conflicts of Dives and Lazarus, of Cain and Abel. The war divided man, crushed the natural correspondences, and brought the concept of mortality very close to everyone. Dame Edith thought that the war was caused by a spiritual blindness. It is Dame Edith's goal to return sight to the blind.

The war, however, is only the external phenomenon which is inextricably related to the internal phenomenon of the mind/body/soul complex of man. The war is the outward manifestation of a host of false concepts. These concepts are learned, are instilled and inculcated into us at a very early age. It is these basic misconceptions which Dame Edith 
tries to remedy. In "The Poet Laments the Coming of old Age," Dame Edith states,

I see the children running out of school; They are taught that Goodness means a blinding hood Or is heaped by Time like the hump on an aged back, And that Evil can be cast like an old rag And wisdom caught like a hare and held in the golden sack of the heart.... But I am one who must bring back sight to the blind. 4

The echoes of Yeats and Blake, and the 18th century methodology of personification by capitalization are obvious. The importance of this quote lies in its statement of role. Dame Edith is the giver of sight. No eidetic sight this. Dame Edith sees reality through the mists of preconception, but in a more universal sense it might be considered that all thought is based upon preconception. The subjectivity with which we view the world is a product of our conceptions and preconceptions concerning the world. Conceptions and preconceptions are the bas is for abstraction and symbol. Dame Edith is the giver of a sight which sees the divine correspondence of all things. She sees things not as they are but as symbols. She believes that there is a very real divine plan unfolding in the world of matter, and she must look beneath the visible to find the essences of earthly life. Therefore, we will find very few naturalistic images within the later poetry. What we will find are symbols which are the embodiment of concepts. The symbols are coprespondent,

4Ibid., p. 309. Henceforth all quotations from Edith Sitwell's poetry will be followed by the page number from this edition. 
cumulative and hopefully universal. Her reawakening of the science of correspondences, showing the essential qualities of Iife, is the sight which she gives to the biind warring wor $1 d$.

The use of symbolism has been seen by Read, Frazer and Symons as a reaction to the fear of the unknown, and there may be a direct relationship between Dame Edith's use of symbolic imagery, and the beginning of the war which brought to her doorstep the meaning of mortality. A quote from Herbert Read will begin our examination of this possible relationship.

We know, from survivals of such geometric types of art among aboriginal tribes today, that the emotion which inspires this non-reprasentational tendency is fear-fear of the unknown, fear of events for which they have no causal explanation. We suppose, on the basis of analogous feelings of our own, that neolithic man was afflicted with cosmic anxiety, a fear of existence or being. Fear breeds secrecy, a desire to communicate in a language that is not understood by the uninitiated-by the hostile forces. Once we assume the need for a secret language of this kind, then particular motifs within the grammar of ornament might acquire symbolic meaning. 5

Read is speaking of the beginnings of abstract art, but there seems to be more than a superficial similarity between the early creators of the geometric pots and the fears which caused Dame Fdith to create her later poetry. Symbolism might be considered as a response to fear. In some ways it may be a veil dropped over the reality of our fears so that

5Herbert Read, Icon and Idea (New York: Schocken Books, 1965), p. 42 . 
they might be more easily assimilated. With reference to symbolism, Arthur Symons concludes,

Our only chance, in this world, of a complete happiness lies in the measure of our success in shutting our eyes of the mind, and deadening its sense of hearing, and dulling the keenness of its apprehension of the unknown. 6 Dame Edith has acknowledged her readings of Symons and Read, and it is their premise that symbolism and abstraction are removals from reality. The shunning of realistic naturalism is an attempt to resolve the common fears of the unknown, as well as the glaring knowledge of real mortality. Symbolism is a response to reality. It is mind expanding in that it allows for alogical correspondences to be considered, but it is mind limiting because of its attitude towards perceptual fact. Both Symons and Read consider symbolism a necessary step in the understanding of the human condition, and Symons, Frazer and Read agree that it is cosmic anxiety that drives man to pragmatically deal with the mysteries of life through symbolism.

This view of symbolism as at least a partial limitation of consciousness is not the only way to view symbolism, because as it constricts the naturalistic vision of reality so also does it expand man's ability to come to grips with the unalterable facts of life. It is the expansion of consciousness through symbolism that is important, for by way of symbolism man can either see or create a workable

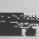

6Arthur Symons, The Symbolist Movement in Iiterature (New York: E.P. Dutton and Co., 1919), p. 89.
} 
metaphysics within which to see himself. It is this vision of man's position between the dust and the angels that allows a certain finiteness to pervade our conceptualization. This finiteness of symbolism is the key to the simplicity and the complexity of the religious symbolism with which we will be dealing. The wheat ear is simple in that it is only a wheat ear, yet through Dame Edith's eyes it is a thing of extraordinary magnitude which, if we look beneath its material form, is representative of all rebirth.

In "The Poet Laments the Coming of Old Age," Time, Goodness, Evil and Wisdom are all exemplified with a certain liveliness that borders on personification. This use of abstraction is an example of Dame Edith's removal away from the realm of reality into the realm of non-representational, non-objective thought. This world of concepts is totally dependent on point of view; this is a fact which she acknowledges in the same poem:

For I, the fool, was once like the philosopher Sun who laughs at.evil and at good: I saw great things mirrored in littleness, Who now see only that great Venus wears Time's filthy A toothless crone who once had the lion's mouth. (p. 309)

Fool or philosopher, little or big, are all judgements based on perspective. They are the opposites from which a view of reality must be derived. Dame Edith wants to give a proper perspective to man, and in order to do this she must find her own perspective. Her perspective is that of an old woman, and as such she sees the world through the concept 
of transiency.' All things decay whether living or dead. Dame Edith will show us that decay is a process of generative Iife. Decay is an act of creation; Dame Edith presents us with the decay/ rebirth, destruction/ resurrection thesis. However, in this poem the only consolation that is given for death is that it takes all.

Not only is her poetry a response to her cosmic anxiety, but also the persona (used as a synonym for role) she assumes is also a response. However, her role as an old woman is not a static changeless role; rather it is a changing, fluctuating and varying role in the sense that the old woman takes on the persona of whomever she chooses in order to fulfill the old woman's desires of religious knowledge and certain other vicarious gratifications which we will see in more detail later. In this poem we see her as a fool, a philosopher, and in some relation to an aged Venus. Later we will see her in her major roles of Eurydice, Demeter, and the Biblically historical earth mother. An example of how even a very minor role can be seen in the context of all the later poetry is the fool of the above quote. The fool is not the stupid bumpkin of cliche; here, the fool is one who blissully experiences the fated, instinctive blood liveliness of youth. The folly of youth has left her; she mourns its loss.

....It can never be caught. Though I bring back sight to the blind, My seed of folly has gone, that could teach me to bear That the gold-s inewed body that had the blood of all the earth in its veins 
Has changed to an old rag of the outworn world And the great heart that the first morning made Should wear all Time's destruction for a dress. (p. 310)

As we have seen, Dame Edith is primarily a teacher, but she realizes that it is impossible for her to teach the folly of youth, when Time has separated her from a true knowledge of it. The only way in which Dame Edith can regain the knowledge of the wisdom of the folly of youth is through trans formation. Not transformation as process, but rather by a somewhat ill-defined switch of identification. In the first stanza of the poem immediately following "The poet Laments the Coming of Old Age," Dame Edith writes,

I drew a stalk of dry grass through my lips And heard it sigh:

Once I was golden Helen... but am now a thin Dry stalk of quaking grass.... What wind, what Paris now would win

My love?-for I am drier than a crone.'

This is just a minor example of a technique used over and over again in the later poetry. As a fifty-two year old woman it is impossible for her to know through recall how the bird blood once danced in her veins (a paraphrase). She solves this problem of knowledge by becoming the mythic figure who represents whatever psychological mood she wished to convey. She literally assumes the character of someone or something, and as such chants whatever most pleases her. Helen is a very secondary figure in the myth complex that Dame Edith develops. A much more important figure is Demeter, who will be discussed shortly. As has been noted, Dame Edith is both a teacher and 
an assumer of roles. However, her Self and her persona cannot be readily separated in any simple fashion. No matter what persona she might assume, it must always be considered as at least a partial representation of Self, and no matter how subjective she might become in her definitions of representational truths, we must always presume that this is at least partially the voice of the persona.

Her main persona is that of the old woman. In the over view, the old woman is a complex of concepts. Each concept is made manifest by a separate image or historical mythical figure. All of these images act as additions to the central figure of the old woman. The old woman, therefore, is a multifaceted anthropomorph built with the logic that created the ancient Chinese zoomorphs. Like the zoomorph, the old woman is the end product of an additive event. As the Chinese added together the dominant aspects of a number of animals to create their Neolithic gods, so does Dame Edith add together the dominant aspects of many different womanly images to create her old woman. Dame Edith creates a complex cumulative product, but the essence is always the same. The essence is that of an old woman waiting by a familiar hearth for a "rebirth of faith and wonder," (p. 251). This underlying essence of rebirth is an acquisition from the Demeter myth. Demeter waits mournfully in the darkness of winter for a rebirth. Rebirth and generation are caused by the combination of the male (the sun/Christ) and the female (the earth/ the seed within the earth). The old 
woman, as we shall see, is the seed within the earth waiting for spring to be reborn.

Demeter is the personification of the corn, but this simple fact reveals nothing of the complexity inherent in the myths associated with Demeter and her daughter Persephone. Sir James Frazer discusses thoroughly these corn goddesses in his Spirits of the Corn and of the Wild. This study serves as the basis of many of the following statements concerning Demeter and Persephone. Their story is a tale of suffering and rebirth. Demeter waits for the return of Persephone, the return of spring. However, both mother and daughter are personifications of the corn. The Greeks plant in the fall, so it could be imagined that the seed entering the earth is Persephone entering Hades, and the emergence of the seed, as shoot, in the spring, could be considered to be the emergence of Persephone from Hades. An equally plausible and mythically substantiated view is that of Demeter, the mature corn, being planted in the fall in order to conjoin with the rains of Zeus in the winter and to give birth to her daughter Persephone in the spring. If only the spring corn was solely equatable with Persephone this interpretation would be quite simple. However, the spring shoots were called green-Demeter and the fall corn, yellow-Demeter. The differentiation between Demeter and Persephone can never be distinguished in the life of the corn, and therefore can never be separated in the Greek mind, who painted them as twin sisters on the early pots. Mother and daughter must 
be considered as a unit. Sir James writes,

Thus far I have for the most part assumed an identi.ty of nature between Demeter and Persephone, the divine mother and daughter personifying the corn in its double aspect of the seed corn of the last year and the ripe of this, and I pointed out that this $v$ iew of the substantial unity of mother and daughter is born out by the portraits in Greek art, which are often so alike as to be indistinguiskable.

Their duality of being easily develops into a mythic representation of death and resurrection. Persephone annually dies in order to be reborn. Demeter, the ripe corn, likewise is sown in the earth to be reborn in the spring.

In the next chapter we will be dealing with a poem named "Invocation." The attitude of Demeter, the waiting mother, is the dominant role in the poem. It sets the stage for the build-up of the complex anthropomorph which will be the old woman. Dame Edith is the old woman; she is sitting waiting, and it is Demeter that is the inspirational image of her being.

T Sir James Frazer, The Golden Bough, 3rd ed. (London: Macmillan and Co., 1925), VII, 88-89. 


\section{"INVOCATION"}

In her Gollected Boems, Edith Sitwell signifies the poem "Invocation" as being the first of her later poems. It is a heavily melodious odic chant reminiscent of the Psalms in the King James Bible. It is a prayer, a supplication, asking that the essence of nature, which is regeneration, return. She begins,

I who was once a golden woman like those who walk In the dark heavens--but am now grown old And sit by the fire, and see the fire grow cold, Watch the dark fields for a rebirth of faith and of wonder.

$$
\text { (p. 251) }
$$

In the opening lines of "Invocation" we find the old woman sitting, waiting, yearning for a rebirth of faith and wonder. Waiting is a solitary event. It is a process of propliation. It is a natural and inevitable sacrifice required by the deterministic fatalism of natural cycles. Rebirth comes via the waiting process. Waiting is a state of being, in which one is capable of experiencing emotion, but quite incapable of acting in a decisive way to mold the concerns of one's fate. The waiting process is caused by the impossibility of determination. The acceptance of waiting is the wisdom of age.

Within this context, it might be considered that age brings with it an excess of time. Waiting is a mark of excess. Youth does not have time to stop and wait for 
rebirth. Youth grows. Oldness waits in the silence of eternity, when every moment is more alive, more catastrophically important than those of youth, but somehow the moments within which one waits are plenty. Waiting is a response to plenitude, and this plenitude is caused by the impossibility of decisive action.

The dominant juxtaposition presented in the first stanza is that of youth and age. When Dame Edith writes, "I who was once a golden woman like those who walk/ In the dark heavens -," she is referring to her own mythic past, as well as the mythic past of humanity. The springtime of Jouth is her past; Edenic innocence is the mythic past of the earth. They are microcosm and macrocosm.

The past is a wishful ideal, to which Dame Edith can now turn, to alleviate her cosmic anxiety, her fear of the unknown. Now, she is grown old; now the heavens are dark. She is a dying fire beside a dying fire. She is now part of the cyclic forces of death and decay which are themselves part of winter's dark fields. Within this landscape of dark fields Dame Fith sits waiting "for a rebirth of faith and wonder."

The dark is the winter, the war, the wait, but within this dark are the seeds of rebirth. As Marx said, "the seeds of destruction come from within." The winter will be defeated and vanquished from the earth, but until then the dark must be submitted to. It is a natural phenomena, a tragic purgative that must take its course, destroy itself 
and return to the creative generative impulses of nature. Within Dame Edith's cosmology war is the spiritual winter. For the gardeners cried for rain, but the high priests howled

For a darker rain to cool the delirium of gold And wash the sore of the world, the heart of Dives. (p. 251)

Bombs are the answering rain which come to cool the greedy hearts which knew not the meaning of "Usura." Bombs produced by the "delirium of gold" return to destroy the mentality which produced them. The answer is within the question.

...the fily-like whispering of small hopes, small fears, The gossips of mean death-gadflies and gnats, the summer world:

The small gilded scholars of the fly

That feed upon the crowds and their dead breath

And buzz and stink where the bright heroes die.

(p. 251)

Instead of realizing his Godhead, man has become so many gadflies and gnats. The language is a little more sophisticated than Pound's Hell Gantos, but the meaning is the same. Where there is economic separation, there is also human separation, or as Marx might say, alienation. The high priests and politicians which perpetrate a system based on greed, pettiness, and transient creeds are the murderers. The victims are the bright potentialities that were once at home within Lazarus and Judas.

The aggressors and the victims are both men. Man is

IEzra Pound, The Cantos $(1-95)$ (New York: New
Directions, 1956), Canto XIV. 
the highest mortal on the great chain of being. Man has potentialities like unto God. In the thought of Dame Edith, man is not only near God, but he is also the possessor of the cumulative evolutionary history of the earth. Within man are all the knowledges of the mineral, vegetable and animal worlds. Man has turned his back on his own greatness. He is blinded by the greed and selfishness of petty ego domination, and has wallowed in the luxury of the monomaniacal egocentricity of the insect.

The end of the first movement of "Invocation" is also the temporary end of the old woman as dominant image. Dame Idith now wants to tell the antithetical knowledge of creation and generation, and therefore she must cast off the clothes of the old woman, and become that which is generation and creation.

The second movement begins,

But I, a golden woman like the corn goddess, Watch the dark fields and know when spring begins To the sound of the heart and the planetary rhythm, Fires in the ieaves and in the hearts of men, Young people and young flowers come out of the darkness. And where are they going? How should I know? I see only That hierarchies love young people-...

The poetic echoes of the beginning of the first movement Prame the beginning of the second movement in such a way as to create a continuity of theme, even though there has been a transformation of being. Dame Edith is now a "golden woman" who is "Iike the corn goddess." Her old role, as watcher of the dark fields, remains, and in addition this second role, as golden woman, brings with it all the 
knowledge that is held within the transmutation of gold, and the transformation of the golden seed to the golden mature grain. The assumption of this new role is the assumption of a new level of consciousness. She now has knowledge of the future. However, she points out that this newly acquired knowledge has its limits. She does not have an ins ight into the particulars of everyday life, rather she can see only the great cyclical patterns of nature, and the ir correspondent reflection within the heart of man. She can now foretell the coming spring, and the reaction of the spring blood within youth's veins. Her knowledge tells of cycles and planetary movements and Time. Time dictates that "hierarchies love young people; "8 the nearer to the darkness of the womb one is, the more clearly can be heard

...the voices that come from the darkness: of the nobler love of Man for his: brother Man, And of how the creeds of the world shall no more divide them. (p. 252)

To have knowledge like that of the corn goddess is to have the knowledge of the seed within the dark earth. The seed is buried as if dead, yet the darkness of the earth acts like the darkness of the womb and generates life from this winter world. Within the womb creeds do not divide man; within the earth creeds do not divide man. The democracy within the dark is the new perspective Dame Edith is giving to man. The

${ }^{2}$ ir James Frazer, The Golden Bough (London: Macmillan and Co., 1925), VII, 170 . 
message is not new, yet the configuration that surrounds the old theme is new.

Finally, it should be noted that Dame Edith uses the designation "corn goddess" rather than Demeter. In many other instances Dame Edith does assume the proper name of mythic figures and historical characters, so it seems that this lack of formal designation might be of some importance. Frazer writes of the European corn goddesses whose rituals survived to modern times. They were called by any one of a number of general names, and perhaps Dame Edith is attempting to relate more closely to her own English ancestory.

The supernatural beings whose existence is taken for granted in them (the rites) are spirits rather than deities: the ir functions are limited to certain well defined departments of nature: their names are general, like the Barley-mother, the Old Woman, the Maiden, not proper names like Demeter, Persephone, Dionys ius. Their generic attributes are known, but their individual histories and characters are not the subject of myths. For they exist in classes rather than as individuals, and the members of each class are indistinguishable. For example, every farm has its Corn-mother, or its old Woman, or its Maiden; but every Corn-mother is much like every other Corn-mother, and so with the old Woman and Ma idens.?

By keeping the corn goddess as a generalized being, Dame Edith allows for a possible racial closeness, and also frees herself from the particulars of the precise Demeter myth within which there might be limitations to which Dame Edith does not want to conform. Being a "golden woman" like "the corn goddess" leaves Dame Edith free to create an individualistic persona, rather than falling into an already existing one. 
Also, the elimination of the Demeter designation, frees Dame Edith from the possible connection between the formalistic aspects of the Fleusinian mysteries and the image of Demeter. Dame Edith is not a pietist. It is the essence of the ritual that is important not the ritual itself. The essence of the corn goddess is rebirth. Rebirth is the knowledge of the corn goddess. The golden woman represents a simple fate-determined knowledge which holds within it all the wisdom of the ages. To Dame Edith there is no greater knowledge than the knowledge that rebirth is all.

Besides acquiring the simple deterministic knowledge of Fate, Dame Edith, by becoming like the corn goddess is participating in a ritual of sympathetic magic. She is acting out a wish fulfillment. She desires that the world once again become a place of innocent fruition, and so she imitates the desired resilt. Her transformation from old woman to golden woman, although the two roles are not mutually exclusive, is intended to bring the regenerative aspects of life to the fore, and by so doing she is seeding the environment with "corresponding" similitudes which hopefully will blossom bringing to fruition her wish.

Because it has been my prime purpose to explicate the fundamental principles of the old woman image as presented in this poem, I have of necessity left out the touching human qualities which pervades Dame Edith's use of even the most grandiose mythic symbol. At the very beginning of "Invocation," she is sitting by the fire watching the fire 
grow cold. The fire represents the life giving aspects of earth, and she is drawing a definite relationship between the hearth and herself. The hearth is the house of the dying embers; she is a house of dying embers. The hearth is also the home of the country Fate. The country Fate is her ideal.

But every life be that of a country Fate Whose wheel had a golden woof and warp, the DayWoven of threads of the common task; and light Tells to the "little child" the common dust Tales of the old world's holiness.

$$
\text { (p. 252) }
$$

A country fate, like the European Corn-mother, is not a prestigeous image. Dame Edith is expressing the democracy of commonality as her ideal. Even the dust is important within her cosmic democracy. Even the dust is alive with importance, and is the "Iittle child." All things are important, because all things are part of God's world. It is this humility that tempers her didacticism.

The country Fate is the brother of humility. Simplicity is their father. They work in the holy fields. The ir common tasks are those of destruction and creation. Life is within all. God is within all.

The humble simplicity of life's deterministic fatalism forces man once again to view his position metaphysically, rather than egocentrically. When the ego is removed, so also are many of the illusions upon which it is founded. No longer can one man be superior to another, for in death "Judas gives again the childish kiss/That once his mother knew, ${ }^{\prime \prime}(\mathrm{p} .254)$. This is the ultimate humility. Only a feminine non-egocentric capacity could see Judas as an 
innocent child. It is an exceedingly powerful image. For not only is humanitarianism carried to a Christian extreme, but this image is a complete refutation of black and white thinking. The mental view that is the embodiment of humility is the eradication of the concept of black. There is always a spark of gold within the dark. Within the darks there is always the goodness that is life.

Within "Invocation" Dame Edith has become both past and present. First she was "I" who was once a golden woman, and then she became "I, a golden woman"; this shift should not be seen as a simple time shift technique. Dame Edith is creating a complex anthropomorph, and in so doing she must become her past and present at once. Fach individual role whether of the past, present or future are as so many heads, arms and legs to a zoomorph. The benefits of this technique are seen by the way she can represent at once both the sexlessness of evening, and the fecundity of spring. In general, Dame Edith is working with an old cliche which finds a relationship between age and wisdom. Her age (evolutionary and present) is important because it represents a backlog of experiential data both mythic and otherwise from which she might draw her wisdom. With regard to her use of evolutionary wisdom she writes,

But if I were to return to that which exists 'below the threshold of awareness, like a sun below the horizon' (to quote $\mathrm{Dr}$. Jung), I might remember that the hair of Judas, according to legend, was yellow, and that he has often been painted in a yellow dress. I might also have a vision of the silent advance 
of the yellow banners of terrible Asian hordes advancing across a vast desert.3

Dame Edith's awareness of the evolutionary knowledges is the aspect of consciousness that separates her from ordinary man. In speaking of her earlier poems she writes,

In many of these poems the subject is the growth of consciousness. Sometimes it is like that of a person who has always been blind and who, suddenly endowed with sight, must learn to see; or it is the cry of the waiting, watching world, where everything we see is a symbol of something beyond, to the consciousness that is yet buried in this earth sleep. 4

This passage is taken from the "Notes" which preface her volume of Collected Poems. It was written many years after her early poems which ceased their outpauring circa 1929. It was written from the standpoint of the artist who created her later poetry. It is in her later poetry that she is trying to correct man's sight. It is the later poetry that assaults the metaphysical consciousness. It need not be pointed out that the images within these passages bear a marked resemblance to the poetry discussed in this section. As an old woman she has the wisdom of age, as a golden woman she has the wisdom of transformation and generation, as a country Fate she has the ideal humility necessary to see life in all things. With these three building blocks presented we await the furtherance of her role's definition in the following poem "An Old Woman." 


\section{III}

"AN OLD WOMAN"

The poem "An Old Woman" is designated, in the Collected Poems, as the second or her later poems. It is in many ways the most important poem considered in my study because of its direct relevance to my topic. The poem is divided into two parts. The first part is unnamed; the second part is called "Harvest." The main images that are added to the developing anthropomorph, that is the old woman, are the images of the old woman as wife and mother. These are not extremely iriportant images, when considered in the context of the whole body of Dame Edith's later poetry, but they are important to our understanding of the role Dame Edith is building for herself.

Culturally women have possessed the role of the receptacle, accepter of the positive; that is male. Dame Edith's old woman holds true to this characteristic.

I, an old woman in the light of the sun, Wait for my Wanderer, and my upturned face Has all the glory of the remembering day, The hallowed grandeur of the primeval clay That knew the flood and suffered all the dryness of the uncaring heaven the sun its lover.

(p. 255)

The old woman waits for the Wanderer that is the sun. It is this fatalistically determined position that negates her possibility of direct action. She is like the stalk of wheat whose face is bared to the mercy of the elements. In 
the impartial light of the sun she stands waiting for her cosmic lover to return. She is the feminine earth that loves the heat of the masculine sun. As the earth she has within her consciousness the earth's memory. She remembers the generative history of the universe. She has intimate knowledge of the creation, the flood, and the dryness of the sun.

Dame Edith derives importance from her knowledge of the past. Her knowledge is the mythic and universally recognizable past of man. She is renewing the cyclical aspects of this knowledge. For the cycle of creation, flood and dryness is the cycle of love. Love creates the flood of passion, which brings about a rebirth of self, and love becomes stable in the secure earthy dryness. Even in dryness, love waits for rebirth.

Her poems keep revolving about the same patterns. Dame Edith waits, as the old woman waits, as the seed waits. Poetically, also, we are revolving. Dame Edith writes,

Though the dust, the shining racer, overtake me, I, too, was a golden woman like those that walk In the fields of the heavens: but am now grown old And must sit by the fire and watch the fire grow coldA country Fate whose spool is the household task. Yet still am I loved by the sun, and still am part $\theta$ f earth. In the evenings bringing home the workers, Bringing the Wanderer home and the dead child, The child unborn and never to be conceived, Home to the mother's breast, I sit by the fire Where the seed of gold drops dead as the kettle simmers And I wait for my Wanderer to come home to restCovered with earth as if he had been working Among the happy gardens, the holy fields Where the bread of mankind ripens in the stillness. 
The old woman is now participating within the framework of a wife image. She is the wife waiting for the husband to come home from work. This is an important addition to the old woman complex of concepts, because as a wife she can much more easily represent the regenerative possibilities of wombman-hood. The wife is a common icon, and it is through this icon that Dame Edith presents us with a more abstract difficulty.

The old woman is a wife and also a mother. But what is she the mother of? The child is dead. The child is brought home by the wanderer. The child is like the seeds of gold dropping dead from the simmering kettle. The seeds of gold are the potentialities of man. Man's potential of evolutionary wisdom, of a spiritual knowledge of correspondences, of the divinity of the blood are all dead. And with these knowledges has died humanity. Man's soul is dead. The child represents the Christian innocence of view that is the window to truth within the soul. The child is brought home dead by its father the sun. The light of the sun shows us what is left of this child-like innocence.

But as one who refuses to yield in the face of death, Dame Edith states,

I shall hold to my breast

My little child in his sleep, I shall seem the consoling Earth, the mother of corn, nurse of the unreturning. (p. 256)

She will take the position of wife/mother/nurse even though her attempts to bring about a rebirth are futile. This is 
the extremity of Dame Edith's skepticism. She suspects that she might be nursing dead issues, but her faith and belief require that she perform her role.

It must be considered that if the child were actually dead there would be no reason to bring him into the poetry at all. By bringing this image to the poetry, Dame Edith makes it a living image. This view is substantiated in a later poem, "A Mother to Her Dead Child."

The earth puts forth its sprałs, the heart its warmth, And your hands push back the dark that is your nurse, Feel for my heart as in the days, before your birth. o Sun of my life, return to the waiting earth Of your mother's breast, the heart, the empty arms. (p. 279)

The child is a parallel force to spring. The child is the object of the old woman's yearning. The old woman has given birth, to this child, now she waits for its return. The child introduced in this poem is a living child, but it is absent from the earthly realm, and when present at the end of the poem, the child is full of a tearful sorrow. So the living child and the dead child are one. They compose an image of the loss of innocent love. The old woman waits for the return of innocent love.

Yet one will return to the lost men, Whose heart is the Sun of Reason, dispelling the shadow That was born with no eye to shed tears-bringing peace to the lust

And pruriency of the Ape; from the human heart's sublimity And teaderness teaching the dust that it is holy,

Bringing love like the daily bread, like the light at morning. 
The return of love; the return of holiness has always been the goal of Dame Edith. She ends the poem,

Though night-long I feel your tears, bright as the rose In its sorrowful leaves, on my lips, and feel your hands Touching my cheek, and wondering, 'Are those your tears?' o grief, that your heart should know the tears that seem empty years

And the worlds that are falling!

(p. 280)

The end of the poem "A Mother to Her Dead Child" is not a positive statement. It is the mourning of a loss. The end of the first section of "An Old Woman" is quite a different story. By her relationship with the Wanderer/sun/. proletarian worker/father/lover she has acquired the right to bless the earth. However, she blesses it not as the old woman, but as the clay of the earth, which holds the earth's history.

. And I, the primeval clay

That has known earth's grief and harvest's happiness, Seeing mankind's dark seed-time, come to bless, Forgive and bless all men like the holy light.

(p. 257)

The old woman has assumed an aspect of the sun. As he was the original lover and blesser of the world, so is she now the active blesser of the world. No longer is she trapped in the role of receptacle accepter, now she is the active party, blessing earth as if she were the priestess of the sun.

\section{II}

The "Harvest" section of "An Old Woman" begins with the same refraining "I, an old woman" that we have seen so many times before, but this time there is no real development 
of the thematic psychological background that the old woman manifests. "Harvest" is the fruition of life; it is the importance of being. At all other stages man is either growing towards something, or degenerating from something. Harvest is the goal of Fate. As we shall see in this Chapter, "Harvest" brings to the fore the importance and beneficence of Fate, as well as the ultimate orderliness of nature. Dame Edith believes that we are determined by Fate; Fate is determined by the Gods, and most importantly she wants to believe that the Gods have us in their care. This is the system; the orderliness although slightly beyond our ken, is there. Dame Edith's creation of an orderly universe eliminates some of the fearfulness from the unknown, the infinite. Orderly universes, like symbolism, only allow understandable categories thereby alleviating cosmic anxiety. Also, a predetermined fatalism is a method of putting God into the mundanity and tragedy of everyday life. Predetermination allows importance and meaning to be seen within the context of daily triviality. It is this external importance of being, that Dame Edith seems to require. However, just because a system of predetermination is being explicated, this does not mean that man is in any way limited in his hopes, desires and actions. In fact, just the opposite is true. Dame Edith's concept of Fate is one of affirmation, liberation and the positive aspects of life. Early in the "Harvest" section she writes, 
But in bud and branch the nature of Frate begins -And love with the Lion's claws and Iion's hunger Hides in the brakes of the nihilistic sprimg.

$$
\text { (p. } 257-8)
$$

Fate is not only affirmative and liberating. It is also energy and desire. Dame Edith uses the Lion in much the same way as Blake used the Tiger. The lion is the color of the sun. This similarity of color signifies that the lion partakes of the sun's energy in much the same way as the ripe golden wheat partakes of the sun's energy. What is added in conjunction with the color is the hunger. Hunger is the instinctual source which leads towards a gratification of a desire. It is this movement towards gratification that is the source of Fate. The plant desires to grow toward the sun. The purpose of Fate is to gratify this desire. The orderliness of Fate is caused by this desire.

The concept of a positive fatalism carries with it the idea of a positive ninilism. Destruction is an incorporated part of nature's plan. Summer must die; Winter must die. The old woman must die; Dame Edith must die. This is the law of Fate. The antithetical hope, which Dame Edith clings to, is the hope of rebirth. There must be another spring, and this spring must destroy the death of winter.

This concept of a necessary and ultimately beneficial Fate is important because it is the foundation of the thought which produced the later poetry. It is this optimism, that man cannot die, that is the bas is of the old woman. 
o sons of men, the firmament's beloved, The Golden Ones of heaven have us in careWith planetary wisdom, changeless laws, Ripening our lives and ruling hearts and rhythms, Immortal hungers in the veins and heart Born from the primal Cause

That keeps the hearts and blood of men and beasts ever in motion, The amber blood of the smooth-weeping tree Rising towards the life-giving heat of the Sun.... (p. 258$)^{\circ}$

Metaphysically, everything is taken care of. All things are determined. We are but cogs in a causal continuum. Our being is caused by our hungers. The "primal Cause" is the hunger within the hunger. God is the hunger within the hunger. To substantiate this line of thinking perhaps we should look at "How Many Heavens..." where we find our most precise definition of God. A blade of grass, which is at once an angel sings,

'God is everything!

The grass within the grass, the angel within the angel, flame

Within the flame,

-God is the stone in the still stone, the silence laid In the heart of silence.'

$$
\text { (p. 299) }
$$

God is the unknowable essence of all being. God is the primal Cause; God is the determination. This is a view that is as valid today as it was in the 17th century when Donne popularized it. It is a view that leads man towards a study of nature, but not nature as a chaotic composite, rather, as a systematized abstraction founded upon medieval hierarchical thinking. Nature is a foreordained system. If we are unable to see its inherent meaning, it is because our knowledge is not as great as 
God's knowledge. (This view of God skirts the borderline of pantheism.) God is one and all at once, God is everything. The systematization of nature is the creation of an abstraction from the elements of reality. Through this seemingly orderly set of appearances man can better see nature as process, or can create for himself, the illusion of process. The process is one of a developmentally ascending series of rebirths which bring men ever nearer to godhood. The problem is that man stubbornly refuses to acknowledge his godhood, and insists on gratifying his petty greeds through his wars. But even within the dehumanizing elements of the capitalist tradition, man might know

...the unborn God in the human heart

Know for a moment all sublimities....

old people at evening sitting in the doorways

See in a broken window of the slum

The Burning Bush reflected, and the crumb

For the starving bird is part of the broken Body Of Christ Who forgives us - He with the bright HairThe Sun Whose Body was spilt on our fields to bring us harvest.

(p. 302)

The above quote is from the poem "Holiday," which represents the idyllic potentialities of earthly love for christ. Dives and Lazarus are joined once again in this spiritual harvest.

However, the "Harvest" section of the poem "An Old Woman" has not developed the view which the later "Holiday" poem has arrived at. In "Harvest" we are still struggling with the basics. The primal Cause (capitalized because it is God), the process of nature, God within man, are all 
concepts which are in an incipient stage of development. A fairly swift clarification of these points might be arrived at, if we see Dame Edith as a post-Freudian who has incorporated within her being the belief that primal desires determine will, and also note that these primal desires are natural aspects of the blood, which holds within it the vestigialurema'ins of the heat of God's first creative impulse.

For is not the blood-the divine, the animal heat That is not fire-derived from the solar ray? And does not the beast surpass all elements In power, through the heat and wisdom of the blood (p. 258)

Dame Edith is making a direct reference to her reading of Harvey. In the forthcoming long quote many of Dame Edith's thematic allusions will have their source made apparent.

The blood, when present in the veins as part of the body, a generative part, too, and endowed with soul, being the sour's immediate instrument, and primary seat...the blood, seeming also to have a share of another divine body and being suffused with divine animal heat, suddenly acquires remarkable and most excellent powers, and is analogous to the essence of stars. In so far as it is spirit, it is the hearth, the Vesta, the household divinity, the innate heat, the sun of the microcosm, the fire of Plato;

the inherent nature of that spirit corresponds to the essence of the stars, so is there a spirit, or certain force, inherent in the blood, acting superiorly to the power of the elements. 1

So now we can readily see the source of Dame Edith's belief in the divinity of the blood, the generative nature of the blood, and the importance of the instinctual animal beats which drive us toward our fate. The divinity of the blood, 
which corresponds to the divinity of the earth's fate, leaves us in a very secure metaphysical position. Man can now stand next to the angels in the hierarchy of being, and rest assured that his actions, if they are not corrupted by the pettiness of greed, will be divinely correct.

So we, ruled by those laws, see their fulfillment. And I who stood in the grave-clothes of my flesh Unutterably spotted with the world's woes Cry, 'I am Fire. See, I am the bright gold That shines like a flaming fire in the night-the goldtrained planet,

The laughing heat of the Sun that was born from the darknessReturning to darkness-I am fecundity, harvest.'

$$
\text { (p. 259) }
$$

A note of desperation is in these lines. This is truly emotional statement. The divinity that Harvey expresses cannot be seen by Dame Edith in the cool prosaic light of rational thought. Her reason is eclipsed by her manifold fears and anxieties, and this statement rings to the unanswering heavens her will to believe. But beyond the emotionalism, she is literally only positing the affirmation of full maturity, and its possibilities of renewed life within the spiritual spring.

Dame Edith ends the "Harvest" section with a fairly conventional Pentecostal image.

The universal language of the Bread(o Thou who are not broken, or dividedThough who art eaten, but like the Burning Bush Art not consumed-Thou Bread of Men and Angels)The Seraphim rank on rank of the ripe wheatGold-bearded thunders and hierarchies of heaven Roar from the earth: lour Christ is arisen, He comes to give a sign from the Dead.'

$$
\text { (p. } 259-60)
$$


Her faith in Christ is the answer to her emotionalism. In Christ there is the security of the ages, the security of the beneficent unknown. 
IV

\section{"EURYD ICE"}

In the previous chapter a correlation was established between the divinity of the blood and the instinctual impulses that determine Fate. One of the more basic impulses of man's instinctual life is the sex drive that precedes human love. This sex drive, physical attraction, or yearning to be, is the subject of this chapter. The old woman, in the role of Eurydice, gives vent to her desires; and through Eurydice and the other roles that follow, Dame Edith develops the actuality of her sexuality within the thematic oantext of the divinely inspired fatalism described previously. Love is divine, if inspired by the hungers of the blood. Love and generation, instinct and divinity are all directly related.

To keep the concept of love as impersonal, and as universal as possible, Dame Edith chooses once again to rely on the mythic past to provide a guise through which she might speak more explicitly. The Greek myths are a fertile field where love is seen as the source of grief and happiness. It was love that drove Pluto to capture Persephone. It was love that caused grief to come to the world in winter. Love causes the emergence of life in spring. Love is the primal cause.

Dame Edith incorporates Persephone's personification 
of death and rebirth into the Eurydice myth. On her wedding day, Eurydice is bitten by a poisonous snake. Death separates the lovers, but in Dame Edith's metaphysics, death (nothingness) cannot be triumphant; death is simply another aspect of the generative fatalism that rules the world. The secrets of life and love are within the husks of death. Dame Edith must go to the underworld to find out the secrets of life, and of love.

As Odysseus and Pound learned their fate from Tiresias, so does Dame Edith/Eurydice, learn from an effigy of Osiris. Osiris is chosen as the teacher because he is the corn god, and the god of the underworld. He, therefore, parallels Persephone's position in Greek mythology. Osiris is the generative dark. Osiris is the means by which dead seeds are transformed to new grain. Osiris transforms the words of Meister Eckhardt, when he states,

We have been blind and stripped God naked of things To see the light which shines in. the dark, and we have learned

That the gold flames of the wheat may spring from a barren heart.

(p. 262)

Meister Eckhardt had said,

The light which God is shines in darkness, God is the true light: to see it one has to be blind and strip God naked of things. 1

Osiris has done what Me ister Eckhardt said must be done. Osiris has seen the light which shines in the dark. The message of Osiris is the message of Eurydice as well as that 
of the old woman. There is no absolute negation. Iife springs from the barren heart. (Frazer relates that the Egyptian peasants buried seed effigies of Osiris, and that the first corn that sprouted from the effigy's breast marked the time of the spring planting.) There is no barrenness, only differing stages of fertility. Fertility and life are verywhere, but, alas, actualities and materialistic realities blind our eyes to the presence of God. "Getting and spending we lay waste our powers." We, therefore, must strip our God of things, of our material needs, and of his societal trappings. We then can see what Osiris tells us. Life is eternal; within the darkness of the underworld there is God, within the stone and the wheat ear there is God. Eurydice states,

...I had learned beneath the earth that all gold nature Changes to wheat or to gold in the sweet darkness.... Love is not changed by Death. And nothing is lost and all in the end is harvest.

God is the gold nature that cannot be corrupted by death. God is love, and love is immortal.

The conclusions of the above quote seem rather contradictory when one considers Eurydice's mythic story. But Dame Edith has changed all that, Eurydice has risen, and when we meet her in the poem she is once again walking the autumnal world, watching the mourning sowers bury Persephone beneath the soil.

Eurydice has been reborn; the earth is heavy with rebirth. 
As the earth is heavy with the lion-strong Sun When he has fallen, with his hot days and rays, We are heavy with death, as a woman is heavy with child,... But as if a lump of gold had changed to corn, So did my life rise from my death. I cast the grandeur of death away

And homeward came to the small things of life, the building of the hearth, the kneading of the daily bread, The cries of birth, and all the weight of light Shaping our bodies and our souls.

(p. 263)

Eurydice is peborn to the ordinariness of the household task, with its own religious rituals of bread and babies. It is this commonality of image that forces us to consider Eurydice as an earthly bride and lover. This is not in opposition to Eurydice's mythic existence. The image Eurydice presupposes that of Orpheus, and these two parallel and fulfill the old woman and Wanderer relationship presented earlier. The old woman waited with her unborn child for her husband, the Wanderer to come home in the evening. When Eurydice is reborn she kisses Orpheus, and Orpheus becomes the Sun (Wanderer).

Developmentally "Furydice" is a very necessary transition. It is a bit much to ask the reader to dwell too long in the old woman's fields of abstraction, and this new image, being primarily and summarily philosophic in content, allows the reader to regroup the old woman mythos under a new heading. Eurydice the reborn lover prepares us for things to come. Immediately following "Eurydice" is a love song, the "Song for Two Voices," here quoted in its entirety. 
10 Dionysus of the tree-you of the bread, you of the

Among the branches of my arms and hair

ripeness

As the boughs of the vine hold the plane-tree-

You came like the wind in the branches.'

'And to the earth of my heart, 0 golden woman,

You are the corn-goddess.'

10 wind, come again to my branches."

10 darkness of earth- 0 ripeness.'

(p. 264)

$(0$ vicarious pleasures restrain your shoulders from transporting me to the very bounds of delirium.) The kiss of Orpheus leads to the conjunction of the golden woman with the golden man. Fulfillment, fruition, ripeness are the order of the day. Metaphorical sexual completion is not without its transcendent aspects. Completion yields ripeness. Ripeness of the seed, and ripeness of the spirit are one. The combination of the old woman with Dionysus is the physical manifestation of the workings of the holy Fate on earth. God is love; love is generation.

This image, combined with the Eurydice image is a major addition to the old woman anthropomorph. Now we see that greed, Usura, the petty desires of men have sterilized. the world of love. This sterility manifested itself in war. Now real love is needed, and real love is within the grasp of all men and women.

Dame Edith began "Eurydice" with the correspondence, "Fires on the hearth! Fires in the heavens! Fires in the hearts of Men," (p. 26I). The fire within man has been lit, now he is like the solar ray. In love, man is divine. The "Song for Two Voices," concludes the preliminary 
poems concerning the old woman. It must be acknowledged that all of the metaphysical foundations have been presented. All that is left is the enlargement of the old woman image, via the incorporation of the established metaphysics within the different frameworks provided by different poems, and of course the changing circumstances of Dame Edith's life. "Invocation," "An Old Woman," and "Eurydice" have all been autumnal/winter poems of death and grief. The "Song for Two Voices" has turned the corner towards the physical manifestation of love that is spring. The two poems which we are about to deal with were written circa 1944. In "One Day in Spring" an old woman is reborn, Her husband tells the tale.

... So after twelve months in her grave She came to me and gave

Her kiss...humbly and pleadingly she crept beside My bed and looked at me with those hollow eyes That seemed as if they had wept For the stains Death left upon her beauty, fearing I might Love her no more--so she came home from her endless nightAnd the lips of my dead love were warm to me....

$($ p. $320-1)$

From this quote it is evident that the story of Eurydice is being retold in a new low keyed assault upon our sensibilities. The husband who tells the story is a "living dead man"; His wife might be considered a dead living woman. This confusion of states of being is for the most part unexplained. I think he is a "living dead man" because without his wife he cannot be complete. Completion is based on the conjunction of the opposite sexes. He is incomplete, and in the spring he calls for her to come back from death's 
kingdom. She does, and he is unable to cope with the

situation.

But the lips, the heart, should be dust-dun, death-cold From that long night... and so I feared to hold

That heart that came warm from the grave....Afraid

Of that eternity of love, I laid

Death's earth upon her heart; for this

Dead man in my dress dared not kiss

Her...

The dead wife had feared rejection. The husband rejects her. His love is dead, and that is why he is part of the living dead. His wife although physically dead, is alive, because she still yearns to love him. Death cannot transform love. Dame Edith after finishing the tale, didactically concludes,

Though all the lovers of the world Grow old, and fade, and die-

Yet how should you and I?

For the world was only made that we should love0 hair, 0 eyes, 0 lips, that will never grow old!

With this ironic conclusion Dame Edith is exposing the falsity of the springtime view of love. Life is change, transformation, glorious growth and degeneration. Life is rejection as well as affirmation. This poem is the first time a relatively realistic rejection or personal negation is expressed in her later poetry. Although spatially distant from "Eurydice," thematically it is an immediate juxtaposition. If Eurydice really did come back, would Orpheus kiss her, or would he be like the living dead man? "Eurydice" and "One Day in Spring" prepare us for Dame Edith's relationship with Pavel Tchelitchew. The relationship between Pavel Tchelitchew and Dame Edith is a rather large unknown quantity. They did know each other, 
and it is inferred in her letters and autobiography that they did live together in a house in France for an unknown length of time. "The Iwo Loves" is a poem dedicated to Pavel

Tchelitchew and his work in progress. The poem begins with another modified Eurydice or Persephone image.

The dead woman black as thunder, upright in the Spring's great shroud

of flowers and lightnings, snows and sins and sorrows, cried like the loud

Noise of spring that breaks in heart and bud... loh, should you pass-

Come not to this ground with your living lass:

For I have a light to see you by!

Is it the Burning Bush?

Is it Damnations Fire?

Or the old aching heart with its desire?

I only know I tried to bless

But felt that terrible fire burn to the boneBeneath time's filthy dress.'

(p. 324)

The old woman is the blesser of all things; she is also the one who wears time's filthy dress. The old woman in the last two poems has been struggling with certain aspects of reality. Rejection was the element of realism offered in "One Day in Spring"; the duality of love is our realistic tid-bit of this poem. The light and heat of Fate, whether manifested in the "burning bush, "damnation's fire" or the old "aching heart with its desire," is love, which is the cause of all things. The double aspect of love is seen in its affirmative pentacostal rushing of flames which is antithetical to the negation of rejected love. Rejection is still very much in the poetry. It is rejection that causes the death of Dame Edith's love. However, nowhere in this poem are we given a precise enough image to really 
know what is happening; we can only know that Dame Edith feels rejected, and this poem is a response to her feelings. The old woman has learned of love through death. She has learned that spring is also a type of shroud. Now she rises and warns a young couple to stay away from death. Death is evil within the context of the Eurydice myth, because death separates the lovers. This separation negates all posibility of sexual comingling and its generative product. Rejection, separation and death are the negative aspects of love. Dame Edith, the narrator, is hurt, She is feeling the psychological pains of rejection, and she is wondering what life and love is really all about.

But where are the seeds of the Universal Fire To burn the roots of Death in the world's cold heatt? The earth of my heart was broken and gaped low As the fires beneath the equator of my veins. And I thought the seeds of Fire should be let loose Like the solar rains The light that lies deep in the heart of the rose; And that the bloom from the fallen spring of the world Would come again to the cheek grown famine-white as winter frostWould come again to the heart whose courage is lost From hunger. When in this world Will the cold heart take fire?

(p. 324)

Dame Edith is possessed of a heart that is cold and alone. The fire, the light, the bloom that were expected, came not. But in the summers of the past these things did come; there was a time when she had her love, and they were both born anew together.

In such a heat of the earth, under

The red bough, the Colossus of rubies the first husbandman and gravedigger, the red Adam, Dug from the earth of his own nature, the corn effigy 
of a long-buried country god, encrusted with earth-virtues, And brought to a new birth

The ancient wisdom hiding behind heat and laughter, Deep-rooted in Death's earth.

$$
\text { (p. 325) }
$$

Pavel is Adam/ Osiris/ the first man/ the husbandman/the grave-digger. He was great because he was all these things, and through his being, Dame Edith was allowed to become his vision (created by Dame Edith) of woman-ness.

... the lover seeing in Woman the rankness of NatureA monstrous life-force, the need of procreation Devouring all other life... Or Gravity's force Drawing him down to the center of his earth.

(p. 325)

Woman is the means of generation. Woman provides the centrality of the combined beings. Dame Edith needs Pavel, needs his image of her, but he has gone. Pavel is in the U.S.A.; he remains there the rest of his life. Dame Edith feels rejected, and this poem is at least partially concerned with her reminiscences of her once fulfilled being. She remembers the oneness that came through love. God had been manifested through them in their gratification of the ir blood's desires, now all this is gone, and Dame Edith recalls all the grandeur of her previous imagery, and anticipates the complex Rose imagery to come.

I see Christ's wounds weep in the Rose on the wall. Then I who nursed in my earth the dark red seeds of FrireThe pomegranate grandeur, the dark seeds of Death, Felt them change to light and fire in the heart of the rose....

$$
\text { (p. 326) }
$$

Christ is seen in direct relation to her personal sadness. Christ and the Rose and the seeds of Fire (instinct) and the pomegranate of Persephone are all brought in to express 
Dame Edith's loss of love, which is not merely her own personal loss, but the loss of love from the war torn world. Dame Edith knows that only Christ can bring back love to her, and she calls to him,

... One who contracted His immensity And shut Himself in the scope of a small flower Whose root is clasped in darkness... God in the span of the root and light-seeking corolia... with the voice of Fire I cry-

Will he disdain that flower of the world, the heart of Man?

$$
\text { (p. 327) }
$$

God is taken to task. He is asked the old question, why is misery allowed. He gives no answer. The answer of course must come from within. Dame Edith is left yearning to be reborn as Eurydice was reborh but essentially she is still the old woman waiting by the fire "for a rebirth of faith and of wonder." 
POEMS $\quad 194.5-1949$

I

It would be mistaken to think that every role or persona which Dame Edith assumes brings about fundamental or even substantial changes in the characteristics comprising the old woman. Rather, her position as old woman is so encompasing as to leave out nothing that is essentially generative. In this chapter, we will see Dame Edith assume a variety of cultural roles. But whether she be Minoan Priestess or English Lady there is no element of foreignness of experience. She assumes the roles in order that she might present different knowledges, and in so doing she becomes universally knowledgeable. The secret of this process is that Dame Edith has all the knowledges within her from the very beginning. Her assumption of a role merely triggers an outpouring of inherent knowledge which might have lain dormant, if her new role had not been assumed. As has been previously inferred, all evolutionary systems carry with them the suspected possibility of other than human knowledge, and likewise, all systems of reincarnation are founded upon other than personal knowledge. Dame Edith was not unfamiliar with reincarnationary speculation. (At one time she believed herself to be the reincarnation of Queen Elizabeth I). But apart from any specious theorizing, Dame 
Edith was familiar with Lorenz Oken's Elements of Physio-

nilosophy. This is a generative history of the universe, and one of his basic principles is very similar to traditional microcosm, macrocosm metaphors. To be a microcosm, man must necessarily have within him the knowledges of the macrocosm. Iorenz Oken writes,

...I showed that the organism is none other than a combination of all the universe's activities within a single individual body. This doctrine has led me to the conviction that World and Organism are one in kind, and do not stand merely in harmony with each other. From hence was developed my Mineral, Vegetable and Animal systems, as also my philosophical Anatomy and Phys iology. 1

By assuming various but similar roles, Dame Edith is doing nothing more than becoming Oken's individual. All activity is within her; she need only recall the activity through an assumption of the role. Therefore, the role she chooses is not really a role at all. More accurately, the role is a study of self. Dame Edith is an old woman by her own admission; and as such is making a study of the composite aspects of an old woman.

One of the old woman's more constant desires is for religious authority. This has been quite obvious since the beginning of this paper. She is possessed of a very definite need to relate herself to religious mysteries, and even to become religious mystery. This need or desire is made manifest in the "Bee Oracles." Here she is keeper of the

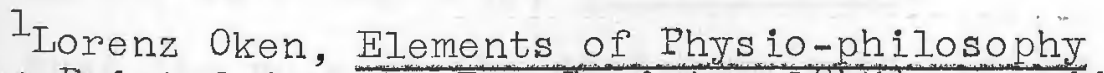 (London: Printed for the Ray Society, 1847), p. xí.}


bees, and the translator of the voice of these natural mysteries. The introductory section states,

In the plain of the world's dust like a great sea, The golden thunders of the Lion and the Honey-Bee In the Spirit, held with the Sun a Colloquy

Where an old woman stood-thick earthinessHalf Sun- half Clod, A plant alive from the root, still blind with earth And all the weight of Death and Birth.

She, in her primitive dress of clay, bent to her hives And heard her sisters of the barren lives

Begin to stir...the Priestess of the Gold Comb Shaped by darkness, and the Prophetesses Who from a wingless pupa, spark of gold

In the dark, rose with gold bodies bright as the lion, And the trace of the hand of God on ephemeral wings To sing the great Hymn of Being to the Lost:

(p. 331)

Here we see the cumulative power of Dame Edith's poetry manifested in an extraordinary way. Eecause of our previous reading we understand the vegative characteristics of the old woman stemming from Demeter, we understand how it is that the old woman is half clod and half sun, and we also understand why it is that she is keeper of the bees. She is the keeper of the bees because they are the little sparks of gold existing within the dark. The old woman is the nurse of the generative dark. It is through her that these sparks of gold will realize their potential. She lends her voice so that their instinctual song might be heard within the human context.

In her autobiography, Taken Care Of, Dame Edith states that the role of the poet should be similar to that 
of the Sybil, not as a particular mythic figure, but in the more general sense of prophetess or priestess. This SybilIine aspect of the Bee-keeper is the present connection between the poet and a position of religious authority. As translator of the bee's son, Dame Edith is in the position of intermediary between higher knowledges and mankind. This relationship with the bees justifies her didacticism, and also allows her to hold the desired position of the one who gives sight to the blind. As transcriber of the bee's "Hymn of Being," Dame Edith fulfills her theologically oriented authoritarian desires. Here, she chants the hymn with all the pietistic repetition of the initiate. What she has previously done for herself in the "I, an old woman" chants, she now does for all being. The bee priestesses chant,

This Earth is the honey of all Beings, and all Beings Are the honey of this Earth ... O bright immortal Iover That is incarnate in the body's earth0 bright immortal Lover who is All!'

'This water is the honey of all Beings, and all Beings Are the honey of this Water ... O the bright immortal Lover That is in water and that is the seed

Of Life... O bright immortal Lover who is All!

This Fire is the baney of all Beings, and all Beings Are the honey of this Fire ... O bright immortal Lover That is in fire and shines in mortal speech0 bright immortal Lover who is All!

'This Air... etc.'

'This Sun... etc.'

'This Thunder... etc.'

This was the song that came from the small span of thin gold bodies shaped by the holy dark. 
And the old woman in her mortal dress of clay

(That plant alive from the root, stili thick with earth) Felt all the saps of Day.

The "Iymn of Being" is the song of the bees who are representative of the gold sparks of life, and who produce, by acknowledgement, the essential honey of life. The bees see the four elements plus the Sun and the thunders as the essential lovers, whose love, whose passionate instinctual drives create life, all life, even unto the vegetative old woman whose roots feel "the saps of Day." The "Hymn of Being" is a hymn of generation; to be, is to participate in the generative process.

Dame Edith speaks of the source of this hymn.

These verses are founded on the great Second Adhyaya of the Brihadaranyaka Upanishad: This earth is the honey (madhu, the effect) of all beings, and all beings are the honey, or madhu, the effect, of this earth. Iikewise this bright immortal fusion incorporated in the body (both are madhu). He indeed is the same as the Self, that Immortal, that Brahman, that All,' etc.?

This element of formalized religiosity is what she could not find in Oken. She could not be a priestess to an unfounded Okenian cult. The beliefs of Oken correspond neatly with these ideas of the Upanishads, but the Upanishads have the accepted grace of traditions, the mystery of the orient, and the romance of non-platonic systematization.

Dame Edith was moved by the verses of the Upanishads. The old woman is made alive by the hymn; she feels the flow 
of life within her, and she is kissed by the great gold Sun. This kiss planted on her cheek affirms and strengthens her being; she now knows that "gold Combs lay/ In the cold rock" $^{\prime \prime}$. 333), and that there is life in the inanimate, that there is life in her decrepitude.

The Upanishads and the hymn place Dame Edith in the desired position of religious authority. They give her a knowledge which she can convey in much the same way as her roles give her knowledge. This position of conveyer of knowledge, or the conveyer of the word is the position of the Sybil, the priestess. By knowing what is (to be), Dame Edith can show the way.

Dame Edith has brought the image of the old woman to a new realm. Previously any reference to the dogma of an organized religion would have been out of place. Her duty as the old woman was to bring us to the essence of things. This could be done through abstractions, symbols, and mythic figures, but never dogma. However, a dogma always did stretch itself just beneath the surface of the poetry. It was her own dogma. Now, we have the acceptance of an organized theological dogma, which is similar to her own conclusions, and similar to her accepted readings. With this acceptance of organized religiosity, Dame Edith descends from her corn-goddess stance and becomes the voice of the bee priestesses who are the volce of dogma. The second half of "The Bee Oracles" is called "A Sleepy Tune." Dame Edith is no longer simply an intermediary 
between the bee-priestesses and man. Now she is able to hear at first hand the words of Osiris. The how and the why of this communication is left to the imagination of the reader, but we do know that Osiris begins his tune with an old familiar phraseology.

I I was a Gold man.... Now I 1 ie under the earth, And only the young wheat-ear

Grows from my hollow breast like a gold sound... Amid the asp-aspersions of the dust, Whe old assertions

Of that sleep-causing asp with swelling head. And only the bull voiced thunders of the gold ripe wheat Answer the Augur in this long and sleepy August.'

The GoId Man who was King raised up his sleep head... 'Is this the time of our advance upon the Sun?

Will he kiss the loveless And stretch himself on our earth in love once more? Lions do not bury gold and seek again The ir treasure... but the sun sees our gold nature Sunken in the earth, and comes again to the Ore, The growing plant and the root with the nature of gold (Whose generation is in the earth) - the Ore, precursor of the plant kingdom, that with the growth becomes alive. (p. 333)

"A Sleepy Tune" is concerned with the myth of Osiris. The Osiris of pietism is not here; it is the more essential Osiris of Frazer. Frazer relates that Osiris was referred to as the "Old Man" or the "Gold Man," and these are the designations Dame Edith uses in "A Sleepy Tune." These names are easily recognizable as being the male counterpart of the Demeter designations, old woman, gold woman, corn goddess. As Persephone is the queen of the underworld and also the goddess of corn, so is Osiris, king of the underworld and god of the corn. They are both personifications of death and rebirth and as such should be seen in the light of al1 
the rebirth personae discussed previously. Also, they are the sexual oppositès that contain within their total knowledges all the wisdom of generation. Tiresias did not know what these two combined figures know. Between Qsiris and Persephone hangs all generative knowledge.

For many centuries generative knowledge has been inextricably related to the story of Adam and Eve in Christian mythology. The speech of Osiris brings into Dame Edith's poetry this Judeo-Christian element in the form of an asp. The relationship between the asp and the dust is not specifically clear at this point, but it appears to revolve around the conventional religious symbolism concerned with the snake as conveyer of knowledge, and knowledge being the death of one state of awareness, or being, and the beginning of another. The asp asserts itself because change, metamorphosis, transformation, constitute the rule of life. The dust, that is asp-like, is part of this process.

After this first section of "A Sleepy Tune," the poem degenerates markedly. Dame Edith plays with some ideas which will be repeated in her later poetry, but none are of any consequence, until the very last verse paragraph, where Dame Edith once again assumes the role of the old woman/ commentator/ bee-keeper and recollects Osiris final speech. ...the Gold man, lying in the dark like the wingless pupa That lies in their cells, said, 'I hear the solar jubilation

Come to the heart and Saps of Being... the roar of ripeness. For the Sun is the Ardent Belief That sees life in the aridities of dust, In the seed and the base excrement and the world's fevers.... 
Seeds and snakes and dust and base excrement and fevers seem to add up to something not entirely non-Freudian. However, this same combination of words if seen through Pauline eyes might not be very differant from what Freud would have found in a case of repression. Aside from Paul and Freud, Demeter and Persephone also were regarded in relationship to snakes in some of the more minor Grecian cults. But these are just sentences of speculation which might be forgotten when we come to Dame Edith's own poetic explanation of her snake imagery.

The snake imagery like all Dame Edith's positive imagery is essentially generative. The snakes of the dust are seen by Osiris who is dead, but also dormant like the bee's pupa. He is both dead and alive, and it is this life of the dust that totally negates any absolute and final death. This life within death is the theme of "The Bee Oracles." To be is enough because to be is to be alive, and to be alive, is to be generative. Dame Edith's speculations along these lines are not based on reason. They are based on Ardent Belief, and it is this belief that is Dame Edith's answer to all her darker questions. Belief quells the storm of cosmic anxiety. Belief implies direction. Dame Edith believes that our fates are directed by powers and instinctual juices beyond our control. These juices of the tree and the animal were created by God, and they determine his manifes tation. God is generative impulse; we manifest God through generative impulse. 
As can be seen Dame Edith does not accept Christian symbolism within the narrow confines of orthodoxy. Christianity is a a religion concerned with the individual soul, with individual salvation, and Dame Edith takes an individualistic view of the Christian religion. Her God is all encompassing. Where orthodoxy might have a dichotomy, Dame Eith might find a unity. Dame Edith develops the imagery of previous beliefs to her own purposes. We saw this quite clearly in the Greek my.ths as interpreted by Dame Edith, and we see this also in her use of Christianity. We are now dealing with the poetry written after 1945. Her spinitual ascendence towards the Christian godhead becomes more and more apparent as we head toward the years of her conversion (circa 1954).

At the end of "The Bee Oracles" Osiris tells of the coming of Christ.

... He comes to the criminal whose nature Was crippled before his birth by a new gravitation That changed the solar system of the heart To a universe reigned over by deformation.... None is condemned.... Then why should we lie loveless? $\mathrm{He}$ will clothe us again in gold and a little love. (p. 335)

This tag-on ending is like the splash of cold water in the face. The poem has been composed of the introduction of the old woman as bee-keeper, her rendition of the "Hymn of Being, "the speech of Osiris, the bee's second song concerning the fair haired Alexander (not included in this discussion), and now these last words that Dame Edith hears from the mouth of Osiris. These words which speak of the deformation 
caused by the radiation and explosion of the nuclear bombs on Hiroshima and Nagasaki, tell us that more has been destroyed than buildings and people. The bombs deformed the heart of man. Man murdered man. The sacredness of being has been totally negated. No longer does man acknowledge the divinity of man. Man has forced the hand of Fate; hie has created unnatural sufferings, and his only hope is that Christ will come, and be our salvation. Therefore, we need not feel condemned. Christ has us in care. This combination of salvation and nuclear reaction leaves us with a very very low keyed optimism.

\section{II}

In juxtaposition to "The Bee Oracles" is a poem which is representative of the way man contradicts the great "Hymn of Being." The poem is derived from a letter written by Mary Stuart to her lover James Bothwell. It is a poem which fluctuates between being a love letter to James Bothwell and a lament of her participation in the premature death of her husband. The poem is concerned with her guilt, her husband's guilt of faithlessness, and her love for Bothwell. All three concerns are inextricably related. It was a personal selfishness which caused her husband, Darnley, the leper-king, to be unfaithful to her; it was her own selfishness which allowed Mary Stuart to ignore Darnley in his time of need; and it was an extreme selfishness on the part of Bothwell which allowed him to participate in the murder, thereby negating 
Darnley's importance of being, and denying him his right to be a part of God's great generative plan. Therefore, it might be concluded that this poem is concerned with the impurity of the blood lust. In the earlier poems, the war was the great antithetical el ment which contrasted life's generative principles. Now love itself is seen as a complex composed of antithetical elements. Love that had been the simple purity of Fate, now takes on a certain hellish aspect. This poem is the acknowledgement of human evil within Fate. The poem begins in the voice of Mary Stuart.

o you who were my heavenly pain of Hell, My element, my Paradise of the First Man That knows not sin-the eternity wherein I dwell! Before the Flood were you not my primal clay?

Did you not shape me from that chaos to the form

of that which men call Murder-I, the light of the First Day?

Mary Stuart sees relationships between heaven and hell that cannot be regarded as truths within the finite bounds of Dame Edith's benevolent God inspired system. Heaven/hell, paradise/first man (knowledge), sin/ eternity, flood/ primal clay, chaos, and form. These combinations are all interrelating concepts which cannot be neatly separated from each other, and they mark an important addition to the old woman image.

Ideally first love, first man bring about a transformation in the lover so that she is created into a new generative being. This change through love is the same as the optimistic determinism that Dame Edith sees working in the essential causes of Fate. With an unfaithful husband, Mary Stuart could no longer participate in Fate's natural 
cycle. His selfishness created in her a selfishness that knew no morality. Mary Stuart can still use the words right and wrong, heaven and hell, but their meanings are confused. She thinks that she has done right by ignoring her husband. Her refusal to pity him, to care for him is totally justified within her mind. She is possessed by the selfishness that is exclusive of all higher laws, especially that of the bee's, who found divinity in all things.

Selfishness cannot see the divinity of all things. It can only see its own divinity. With Bothwell, Mary Stuart participates as a holy generative unit, but this unit is defective because it is exclusive, not inclusive. Within this poem we no longer see the old woman loving completely without limits. The Mary Stuart poem brings out the selfish, possessive aspects of love.

But how should Pity stand between you and me!

The Devil sunder us from our mates, and God

Knits us together

Until nor man nor devil could tell lover from lover

In our heaven of damnation! Could these sunder our clay Or the seas of our blood? As well might they part the fires That would burn the bottom of Hell.... But there is no $\mathrm{Hell}$

We have kissed it away.

$$
\text { (p. 337) }
$$

The ending of "The Bee Oracles" juxtaposed the atomic bomb against salvation. The above ending juxtaposes a living love with death. It was the extremity of self love that allowed us to drop the atomic bombs; it is a similar love which allows Mary Stuart to let her husband die. Her selfishness allows her to see only herself, and her limited vision is a direct denial of the divinity of the blood that is in 
all men. The blindness of Mary Stuart and the blindness of the bomb-droppers exemplify the blindness which Dame Edith is trying to eliminate.

Developmentaliy the words used in the Mary Stuart poem are of interest because they bring the old woman image to the words and concepts which are the framework of the sociology of Catholicism. Heaven/Hell, Paradise/First Man, sin/eternity, Flood/clay are all elements which we have previously seen in her poetry, but never before had they been brought together in such a way as to jar us out of our pantheistic complacency and confront us with the harsh reality that her systems building is slowly turning into a form of Catholicism.

\section{III}

It seems that this chapter jumps from one thing to another like a stone skipping on water testing each circle of influence, and this is exactly what the poetry between 1945 and 1949 is like. "The Bee Oracle" is an important poem, but after the poem both the bee imagery, and the references to the Upanishads cease, except for very minor echoes. Also the Mary Stuart poem is a dead end as far as personal and "reasonable" murder is concerned, but the Catholicism that was introduced leaves the indelible mark of Paul on all the later writings. No longer can love be totally good, wholesome and pure. Now there will always be complications of guilt and selfishness and possession. 
However, as her theories work their way to fruition, even the darker aspects of love are incorporated within her metaphysical system of Christian generative love.

The Mary Stuart poem is only the first of a series of female oriented praise/lament poems which include the figures, Medea, Dido, Medusa and finally the "Hymn to Venus" which culminates the thematic development of the aforementioned poems, and re-introduces the old woman, who we find praying to Venus.

Lady, beside the great grean wall of Sea I kneel to make my plea

To you, great Rose of the world.... Beyond the seeds of petrifaction, Gorgon of itself,

Behind the face bright as the Rose- I pray

To the seeds of fire in the veins that should

Hold diamonds, iris, beryls for their blood; (p. 343)

Venus is the icon before which she places herself, but as a crucifix is not Christ, so neither is Venus the Godhead. Venus: love is one manifestation of the Godhead, perhaps his primal manifestation, but the old woman wants to pray beyond the image. She wants to pray to what is "Behind the face bright as the Rose" to "the seeds of fire in the veins." The name Venus cannot help but be connected with the blood rush of love on many different levels.

The "seeds of fire" are the elemental essences of the earth from which we were formed. They are the golden jewe Is of life that parallel the bee-metaphor of the beginning of this chapter. The jewels of the blood are the logical conceptual remnants of the beliefs that man has eve-volved from 
the earth and also that gems are divinely symbolic of certain things .

According to Oken's system of nature, there are three earthly kingdoms, mineral, vegetable, and animal. These are developmental kingdoms which have slowly evolved towards the partial fulfillment in man, and their complete fulfillment in God. The essence of all nature, therefore, is found in the mineral kingdom, and the essence of the mineral kingdom is manifested in jewels. Jewels hold the spark and glitter of life, from which all earthly life is derived. A jewel, being an essential quantity must also be looked at as a symbolic entity. Oken does not go into the realms of static symbolism in quite the same way as does Swedenborg, and because Dame Edith has read both, and creates a large part of her metaphysics from both, we will turn to Swedenborg for his interpretatian of the gems listed in the above quote.

The jewels mentioned above make up the blood of the rose. The juices that stream in the rose's veins are mineral in their origin. According to Swedenborg's teachings, the diamond is representative of celestial truth, and the beryls spiritual truth. 3 Thusly, celestial and spiritual truths make up the blood of the rose, which is a parallel to the blood of man, and ultimately parallel to the blood of christ.

$3_{\text {Rev. Fdward Madely, The Science of Correspondences }}$ Elucidated (Germantown, Pa.: The Swedenborg Publishing Association, 1882), p. 530 . 
This last statement is not in contradiction to the poem which sees the rose as Venus. Venus is the love by which Christ is made manifest.

It cannot be said with certainty that Dame Edith follows Swedenborg very closely, but it can be stated that they are of similar thought processes. They both believe in the inherent correspondences of all things to God. The earth and everything within it is a manifestation of $H$ is beneficence. The old woman prays to the rose. The rose is a rather traditional symbol of divine love. Dame Edith does not assume the yellow rose of Dante; rather, she assumes the red rose of the passion. Dame Edith sees a close connection between the passion of Christ, and the passion that is the divinely inspired instinctual passion which determines Fate. Both passions are the means to a form of rebirth. Previously we have seen that sexual attraction is directly related to the love that is divine. The red rose is the rose of the passion in both senses of the term.

The old woman prays to the rose. She is still suffering from the cosmic anxiety that caused her to take up her pen to write the first of the later poems. As she gets older she feels that something is gone from her, something is leaving her, and this makes her feel the guilt of impotent inferiority which requires that she seek reasons for her existence, and yearn for the acknowledgement of her salvation. 
Pit me then- a poor old woman who must wear a rag of Time's filth for a dress....

0 , who would care to hold

That miserly rag now!

So I, whose nights were violent as the buds And roots of Spring, was taken by the Cold, Have only the Cold for lover. Speak then to my dust! Tell me that nothing dies But only suffers changeAnd Folly may grow wise.

The old woman has remained remarkably constant. She is still lonely for the affirmation of a Christian rebirth, and she is still hoping that through change she will become wise. Here we see a more personal tone working than was used within the old woman/Demeter configuration. Demeter by her position knew that rebirth is inevitable. The old woman without this role is not quite sure, but nevertheless she repeats her belief as if assuring herself that what she wants to be, will be.

So, Lady, you and I

And the other wrecks of the heart, left by the Lion Of Love, shall know all transmutations, each degree! Our apish skeletons, clothed with rubies by the light Are not less bright"

In the Sun's eye than is the Rose... and youth, and we, Are but waves of Time's sea.

Folly and wisdom have dust equal-sweet, And in the porphyry shade

Qf this world's noon

The Poor seem Dives, burning in his robes bright as the roseSuch transmutations even the brief moment made.

(p. 345)

Transmutation, transformation and change is still the rule of nature. The old woman is in process. Although she appears and feels old, she is in the process of being made anew. Transmutation is taking place in her even within this very 
moment. This is the answer she desires. She needs to know that she will be reborn anew, again.

\section{IV}

The Venus/Rose/Christ imagery is climaxed in the poem "The Canticle of the Rose." Here the Rose chants its song,

The Rose upon the wall

Cries-'I am the voice of Fire:

And in me grows

The pomegranate splendor of Death, the ruby garnet almandine Dews: Christ's wounds in me shine!

Pomegranates are a fruit representative of Truth. Persephone had to eat of the pomegranate before Pluto would allow her to return to the earth. The "pomegranate splendour" therefore refers to the truthfulness of immortality, of the ever returning cycles of life and death; as well as the red color paralleling that of the rose as a symbol of Christ's passion and resurrection, and man's salvation. The truthfulness of the cycles must be seen in the light of Dame Edith's beliefs. The blood of man like the blood of the rose is possessed of divinity. The divinity of the blood puts us in direct relation to the suffering of Christ, from which something should have been learned. The Rose is "the voice of Fire," because it is the heat of the blood that is the proof of divinity. After the Rose's opening chant, Dame Edith presents us with a series of digressions. The first one follows, There was a woman combing her long hair To the rhythm of the river flowing... She sang, 'All things will endLike the sound of Time in my veins growing: 
The hump on the dwarf, the mountain on the plain, The fixed red of the rose, and the rainbow's red, The fires of the heart, the wandering planet's painAll loss, all gain-

Yet will the world remain!

(p. 37.3)

The subject matter of the poem is the atomic bomb; it is correlated to the crucifixion of Christ. The woman of the first digression presents us with the extent of the old woman's optimism. Things will carry on; the world will remain. Man has committed atrocity after atrocity, and it seems that he is unaffected by Christ's suffering. Dame Edith participates with the woman of the poem in a very low keyed optimism. But the Rose that is Christ's passion has a greater view than does the woman of the poem, or Dame Edith. The Rose has suffered and has been resurrected. The Rose is a resurrection and as such is an example of Christ's bountiful goodness.

But high upon the wall

The Rose where the wounds of Christ are red Cries to the Iight-

'See how I rise upon my stem, ineffable bright

Effluence of bright essence....From my little span

I cry of Christ, Who is the ultimate Fire

Who will burn away the cold in the heart of Man.

Springs come, Springs go....

"I was reddere on Rode thä the Rose in the rayne..."

The smell is Crist, clepid the plantynge of the Rose in Jerico."

(p. $37: 4)$

So we have ascended from the depths of paganism to the heights of Christianity. This is the tendency of the rest of the later poetry. Osiris, Demeter, Venus and all the athers become of less importance, and the Christian myth comes to the fore as the culmination of the earth's mythic past. 


\section{VI}

POEMS $1949-1954$

Because of Dame Edith's rising interest in Caubolicism, and because the importance of the older pagan myths has begun to ebb, the presence of the Demeter-like old woman also diminishes markedly. In the poetry to be dealt with in this chapter (1949-1954), the old woman and the poetic voice of Dame Edith are one. That is, the old woman is still a persona; she is the formal dressing gown of the poet, only now there is no physical manifestation of the old woman as a separate entity. There is only the voice of the poet.repeating, and establishing themes whose foundations Iie in the generative mythic figure of the old woman. We will still meet the old woman again from time to time, but the differentiation that might have previously been determined between Dame Edith and the old woman has now disappeared. They are one and the same.

One of the reasons for this disappearance of differentiation is probably because she is now within the Christian mythic framework, and as such it is quite impossible to justify the creation of a being somewhat different from the author, who expresses a point of view different from the author's. If this were done it would have to be condemned as hypocrisy. The author's voice, and the volice of the character created must necessarily become one. The first 
poem of this section is "Bagatelle"; it begins,

Upon the soil-(crushed rubies? Or the pomegranate's garnet seeds?)

And ridges with mounds like graves

of giants and earthworms - two Noachian survivors contemplate Their glories of the past, the ir future state.

The small red Worm, rubied with dews of death, declared:

My redness is from Adam....

And I have brothers

Who live in the flesh of Negroes, and are thick

As lute strings, and as powerful. I have others

Who sing the praise of Death with a sweet tongue--

Great venomous serpents in the unknown Africa;

(p. 377)

The serpent of Christian symbolism has come to the fore. The earthworm, the snake, the serpent, the maggot, the ring-worm, the hook-worm, all participate in the Fate determined generative process in their own way. They are all related to each other in two ways. First they all participate in the process of decomposition, and secondly, they all have a metaphorical resemblance to Eve's friend, and his relationship to knowledge. It is through him that the christian learns to partake of, and participate in the mysteries of the generative life. On another level, it is through the earthworm that man is physically reborn. The golden sparks within the flesh of mankind ascend the veins of the tree only through the process of decomposition. The earthworm is a symbol of the decomposition process. Decomposition equals rebirth. The poetry with which we are now dealing is not at all divorced from what has gone before. The earthworm is a red worm. Red is the color of the Rose, Christ's passion, and the divine blood within the heart of man. The worm is 
red by association. It becomes the color of its food.

The Worm said, 'I am small, my redness is from Adam, But conquerors tall

Come to my embrace as I were Venus. I

Am the paramour in the last bed of love, and mine, the kiss That gives eternity.

I am Princess of Darkness. Yet the huge gold world,

With all plantations, power of the gold growth that shall be the bread of men,

Arise from the toil of the small, the mighty Worm beneath the earth,

The blind, all seeing power at her great work of death and of rebirth.

$$
\text { (p. } 378)
$$

The Worm is the Princess of Darkness, and as such fulfills a very similar role to that of Persephone and also Osiris, who were personifications of the wheat, and of rebirth. The worm also represents rebirth. Love is his instinctual desire to do what he does, through his love man is reborn. The earthworm combines with the corpse, and by so doing spreads the corpse's sparks of gold throughout the soil. The sparks of gold enter the roots of the vine and tree, and man is reborn. As Persephone and Osiris were transforming spirits within the mature wheat seed, so now is the earthworm a transforming spirit. The earthworm is representative of the decompositional physical transformation of nature, and also the love, the instinctual desire that keeps the worm active and keeps all the planetary systems in motion. This concept of the worm as conveyer, or bringer of life through love is one of the oldest worm images in the western culture. The worm and serpent are conceptually related. They are both of the darkness because of the unknowable aspects of love. The worm and the serpent represent the darkness of instinctual 
desire. (Consciousness, light and awareness of the sun. The sun knows no particularized desire; the sun loves all things alike.) The worm and the serpent represent the irrational darkness at the root of all positive generative desires. It is the worm's knowledge of the darker side of life which makes him the tutor of man. The worm transforms the life of man both physically and mentally. The knowledge of the worm brings man to fruition as an independent sexual identity; the knowledge of the worm spreads man's sparks through the soil so that man's identity might be reborn.

This relationship between the Worm, Venus, Christ, Adam, Persephone and the old woman will be seen more clearly in the following poem. "The Road to Thebes" revolves around a quote from Aristotle.

Is the road from Thebes to Athens and the road from Athens to Thebes the same?

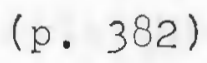

This is a poem divided into three sections, actually three different poems held together by their similarity of theme. The main character of the poem is the "Dead Man," or the worm's workshop. The Dead Man answers the thunders of the spring saps rising; he states,

'Is your gold-sinewed body still a vine-branch In the vineyards of the great Venus?' 'Shrunk to this Poor span, I have returned to the likeness of the first and final worm, that is my brother

For were we not of the same holy motherAlike in holiness?...

$$
\text { (p. 383) }
$$

In this small quote relationships of great magnitude are being created. First, the Dead Man is speaking to the ghosts 
within the vine branches, i.e. post-worm human essences. Secondly, Venus is the mistress of the vineyard, and it is by her love that the ghosts of the dead are reborn in the vine branch. As the resurrector of man, Venus is participating within the Rose/Christ/ passion/ desire/ love/ rebirth/and earth mother complex. Venus is an essential part of the worm's desire to transform the corpse to fertilizer. ...the gilded dust of Venus in the spring, Fertilizing the crocus.

(p. 384)

Venus, herself, has been transformed to fertilizer. The Dead Man has seen this, and knows that he too is potential fertilizer, and that he too will become a ghost in the bough of a tree.

By presenting the Dead Man as something separate from herself, Dame Edith has put herself upon the road of life. As a mortal, her expectancy is to participate in this fertilizing process, and she feels the loneliness of mortality, the cosmic anxiety of her position. She empathizes with the Dead Man when he states, "And I was alone with Iife-the Naked Man" ( $p .384)$. Life is the naked man; Me ister Eckhardt has told us that to see God we must strip God naked of things. The Naked Man is God, and to be alone with Him, is to suffer cosmic anxiety. When Christ was alone with God he thought himself forsaken, and Dame Edith fears that she will be forsaken. To escape from the anxiety produced by the loneliness of the knowledge of the Naked God, Dame Edith reverts to her conceptual maternity, which was the foundation 
of the Demeter myth. In a previous quote, the Dead Man claims to be like the worm in holiness because they have the same "holy mother."

The holy mother seems to be a new addition to Dame Edith's later poetry, but I don't think that it is. This is the poetry that was written in the five years previous to her conversion. The holy mother, therefore, is probably an oblique reference to Mary, although not as an individual character, more as the mother of mankind, which Dame Edith tried to represent earlier in her poetry, when she presented the old woman, as wife of the Wanderer, and mother of an unborn child. It is within this large ideogram of Holy Mother/Worm/ Venus and the old woman that Dame Edith finds the security which she desires. It is this ideogram that teaches her that the road from birth to death, and the road from death to birth, are the same. Womb Tomb St. runs parallel to the road between Athens and Thebes.

The worlds went: I was a clod of earth Blown by the wind along the road from Death to Birth. The world's came: I was clothed with a little dust And blown along the road from. Birth to Death.

I cried at the light, as I had cried at the dark. I found a little rest upon my way, a small child growing Deep in the tomb, or in my mother's wombBut still unknowing.

$$
\text { (p. 385) }
$$

The mother/womb image is inextricably related to security. Dame Edith had earlier given herself the role of the earth mother, this role has been transferred to the holy mother. The holy mother is representative of security not because she shields anyone from evil, but because of the generative 
principles related to motherhood. Generation is still the theme of Dame Edith's poetry; growth, desire, love, generation are all part of the instinctive unconscious determined by God. Generative growth is the restful haven that knows no loneliness. Change and growth are both part of the law of life which cannot be broken. Growth and generation are the physical manifestations of divinely inspired desire and love.

The second section of the "Road to Thebes" is called "Interlude." In this section Eve is presented in conjunction with her namesake evening. Eve was the recipient of the worm's knowledge. Now she is portrayed in Dame Edith's previous role of nurse. Dame Edith was the nurse of the unreturning; Fve is the nurse of generation.

And the golden nodding nurse that we call Eve

And evening, sighed, The first and final Adam, he who is one with the immense Ceres

And al1. day broke the gold body of the giantess as in love. ( $\mathrm{p} \cdot 387$ )

To break the body of Ceres is to break the body of the wheat that is Christ. Adam breaks the body of ceres in an act of love. Adam is joining with Ceres, the Princess of Darkness, the Corn-goddess in an act of union. Love commands us to break the body of the God or Goddess that is generation. The God must be killed or broken in order that man might partake of the God's heavenly wisdom, and learn from the God's body the mysteries of life, of birth and rebirth, which are contained in the wheat ear. In other words, like Osiris, Demeter, and Ceres, Christ was harvested at maturity, and 
because of the harvest all mankind is able to partake of his spiritual goodness

God is broken in an act of Love. Iove is the generative impulse that is the cornerstone supporting Dame Edith's theory of the equality of life and death. Both life and death are founded upon love; both revolve about their respective worms. In continuing this line of reasoning, Dame Edith writes of the "girls, with breasts like points of sun" and of their loves overheard by the branches.

What do the seraphs and sapphires of air among the branches Hear as the voices pass? 'Your hair is ringed as the tendrils Of the first plantations of the Vine after the Flood.'

The vines of the Sun? Or the vines of Darkness and of damnations

The vines of Medusa's serpents?' 'Ah your kiss is the light of the planets, burning among the leaves!'

'No. It was Lucifer,

Son of the morning-then it changed to the Prince of the air, the brightness

That rules in Hell! Grown cold! I am Medusa-and my other Name is Time!

$$
\text { (p. } 387-8)
$$

Transiency, temporality and evilness are representative of the death of innocent love. The death that is inherent in love is the death of the familial consciousness and the creation of an individual consciousness founded upon ideas derived from the knowledge of union. The death of one self and the creation of a new self is the dichotomy of heavenly and hellish emotions which are the means of the physchological change. The love, that is the foundation of the new self, is the possessor of a new perspective. This perspective is not the idealized perspective of the uninitiated; it is the substantial knowledge of the initiate. 
Come to my lips-the long horizon-

Cold with the serpents' buried wisdom, that has known the azoic

Continents, the secrets and night haunted jewels of the catafalques !

Come I will seal your eyes that they shall no more weep No more behold another. Once, at your grief The unfraught sea would swell, and the unsought diamonds Rise with your tears.

Tears have entered the realm of personal love. Mary Stuart's grief has been abstracted to a universal. Tears had always been present in the greedy world where Usura had usurped Christianity; and now Dame Edith has allowed the darkling shadow of evil to spread over the fertile plain. Eve ends her song,

Now you shall faithless be

To the flesh of the orange-blossom and arbutus honey hearted, Seeing my lips, cold as the unburied sapphires in the desert air,

Approach your own:

The one horizon, the azoic continent of night and stone.

(p. 388 )

The end of love is death. Death sends the ghost into the tree branches, away from the earthly lover. Death will force the lover to be unfaithful to his beloved in favor of his new state of being.

From cornucopias and corruptions, continents of growth, from where those seeds, the dead, are sown To be reborn, and germs of evil that exist in Matter Are changed by holy earth, to the common good, To usefulness, fertility, The breath

of the Ardent Belief, of the cultivated earth....

$$
(p \cdot 385-6)
$$

Death ends the hellish aspects of Iove. Death makes all things good and pure. Death is purgation and fertilization. 
The purgative process is founded upon the concept of evil. Without evil there would be nothing to get rid of. Without evil the naturalness of the earth would be allowed to flower and bloom beneath the sun that could see no evil. The concept of evil brings with it the desire for purgation. Dame Edith has come under the influence of the Catholic church, no longer can she be the old woman forgiving and blessing all. Now she not only sees evil within good, but she also judgementally acknowledges the guilt of the world and her own guilt of being. In part III of "The Road of Thebes," Dame Edith presents herself as Eve, the metaphorical ragpicker. This is part of her self humiliation.

What is it knocks at that tomb my heart? Is it the gravedigger,

The final Adam? There was ane knocked so:

He would not know me how. For all Time's filth, the dress I stole from the habitation of the Dead,

Hides me- a body cold as the wind-blown vines,

And the sad sapphire bone shrunk by Time's fires

To this small apeish thing.'

'Ah., how was I inferior to Death

That you should be untrue? Now, kindly Age,

My one companion, holds me close, so I

Forget your kiss.

$$
\text { (p. 390) }
$$

Death/love/ zissing/ knowledge/ evil/ eve/ evening/ age/ Adam are all related. The ideogram is getting so immense that it is hard to conceptualize the myriad of meanings and inferences which exist now in almost every statement. This is medieval metaphorical thinking at its very best. Dame Edith is the thought process by which the ideogram is determined; she is striving towards the essence of Christianity, and 
when we read the last lines contained in this section (19491954) of this poetry, we know that she has found her "Ardent Belief."

If every grain of dust should be SatanIf every atom of my heart were LuciferIf every drop of my blood were an abaddon - Yet should I love. 


\section{VII}

POEMS $1954-1963$

Now that we have explored Dame Edith's dew-dripping worm-filled eternity, we are left with only Dame Edith's final segment of poetry to deal with. This final section of poems contains those written between the time of her conversion (1954), and her death (1964). These poems are additions to the original Collected Poems which were composed and collected, up to and including the year 1963. As a separate section, they have their own Preface, and are themselves the contents of her last book of poems, Music and Ceremonies. The Preface brings us up to date on her views of religion and poetics, and it is of particular interest to the subject of this paper because it is the only place in her prose work where she refers to herself as an old woman. "Now I am an old woman, I remember these lessons learned in my earlier days." Dame, Edith is reminiscing; she is an old woman reminiscing, and the contents of her mind, the things which she remembers must not be considered as things of the past. They are in her consciousness when she is old; they are the gold that has stood the wash of years. Her rememberings are the final beliefs and straws of the old woman.

As the great writer Jean Cocteau said: "The spirit of poetry is indeed the religious spirit outside all precise religion.'

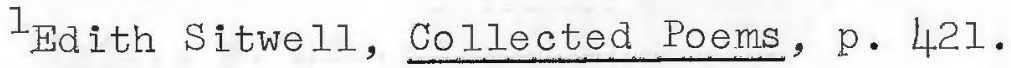


'He from the sunlike centrality and reach of his vision,' said Emerson of Plato, 'had faith without cloud. 2

Dame Edith is using the same method of development she incorporated in her Poet's Notebook. A compilation or collage of quotes creates her justification of herself as well as her poetic stance. Her poetry is her message, but for her justifications and rationalizations she must lean on others. Her technical irecollections are developed in a similar vein. She quotes Coleridge.

To read Donne you must measure Time and discover the Time of each word by the sense of passion.'

Father Gerard Manly Hopkins, in a letter to R.W. Dixon, said, 'Browning has, I think, many frigidities; Any untruth to nature, to human nature, is frigid. 3

By the nature of these passages, it is easly recognizable that Dame Edith is still in need of explanations. She still does not have all of the answers. Her mind has not been frozen by systems or by quotes. She is always fluid, and never unnecessarily frigid.

This gathering together of great truths in the form of small quotes is not limited to this last Preface or the Poet's Notebook. It is also used in the "Notes" on her poetry which follow and complete the collected Poems. It seems that she has always had a tendency to build her

$$
\begin{aligned}
& { }^{2} \text { Ibid. }
\end{aligned}
$$

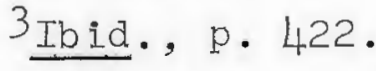


arguments by employing quote after quote in a multiple fashion, until a phalanx of such power is built that it is almost irrefutable. This has also been the method of her description of the old woman.

In the creation of the old woman, Dame Edith added image to image in such a way as to create an all encompassing anthropomorph which would be the embodiment of the earth's generative existence, and which would preach the belief in rebirth by examples from her multi-faceted being.

\section{At the time of her writing this last Preface, a}

large part of her justification of what she has done, and will do, stems from her interest in Wordsworth which has never been a stable value throughout her life. She now resolves her feelings about him; she writes,

I do not mean- I have never meant - that we must avoid the everyday world. Reason and Tranquility were the companion angels of Wordsworth as he walked through the everyday world made splendid by the light of a genius that illuminated but did not transform. Common speech and common experience were there, but all made radiant and unforgettable by inspiration.

There were days - the "Intimations of Immortality from Early Childhood" was such a day- when the pentecostal Flames came, for a moment, to our common speech. The ordinary objects of life became supernatural. The common celandine was still the common celandine, but it was also a star. For Wordsworth had the warmth of the earth and of the human heart; and that genius which was rather of the human heart than of the soul had taken all the chill from reason.

The earth and every common sight

To me did seem

Apparelled in celestial light.'

Poetry is, indeed, the deification of reality, and of its purposes, among others, is to show that the dimensions of man are, as Sir Arthur Eddington said, 
'Halfway between those of an atom and a star. 14

Although Wordswoth was a much more naturalistically representational poet both in his imagery and poetic theory, the main theme of his poetry, natural divinity, is also the bas is of Dame Edith's poetry. Through her meanderings of symbolic self, through role after role, Dame Edith has made the commonness of her own being divine. She has been the old woman, Demeter, and herself, as an independently divine substance beneath the eyes of the compassionate Christ. She created of herself a religious spirit; and like Wordsworth she showed the divinity of her own commonality.

It has taken Dame Edith a lifetime to resolve her feelings concerning Wordsworth, but in so doing she also resolved her attitudes concerning life. Wordsworth was more an individual of essential pragmatism than was Dame Eidith; he knew that he required firm footing for his thoughts and his poetry, and Dame Edith ultimately needed the same. The difference was that Wordsworth was not confused by the concepts of autodidacticism and originality that formed a great deal of the thematic basis for Dame Edith's early poetry. She had to be new, modern, progressive. Wordsworth could grow more naturally.

In the later poetry, Dame Edith has grown naturally. She has remained cons istent and developed slowly both in her poetics and her search for God. 
In the poem "His Blood Colors My Cheek," Dame Edith has borrowed the words of St. Agnes for her own use. The words of St. Agnes are simply a statement of emotion with reference to the thought or the idea of Christ. Dame Edith begins the poem,

I, an old dying woman, tied

To the winter's hopelessness

And to a wisp of bone

Clothed in the world's outworn foolishness

-A poor Ape-cerement

With all its rags of songs, loves, rages, lusts, and flags of death.

$$
\text { (p. 436) }
$$

Generally speaking this is a common image throughout Dame Edith's later poetry, the difference being that before her conversion Dame Edith was an old woman waiting, and now she no longer needs to wait. Christ has come.

His Blood colors my cheek; -

No more eroded by the seas of the world's passions and greeds, I $r$ ise

As if I never had been Ape, to look in the compassionate, the all seeing Eyes.

$$
\text { (p. 437) }
$$

"His Blood colons my cheeks" are the words of St. Agnes. At the end of the poem, there are no quotation marks used. The words have become Dame Edith's. Christ's blood, his passion now has a direct effect on her. Dame Edith is, at least psychologically, saved by the all-seeing redeemer. Dame Edith is now a Christian participating in the process of salvation. She has thrown off the Grecian dominance and has been made anew with a lively Christian vigor.

Catholicism allows Dame Fith to be a truly individuated self. In her earlier poetry, she tried to make 
herself individualistic, and separate from the flow of decadent culture; now she is unique and alone through no effort of her own. In "Song" we see this new found individuality most strikingly.

But I who have known the weight of the August a ir And the gold heat in the heart

Am like a bright small star in the starry sky Bright to myself only.

$$
\text { (p. 440) }
$$

Dame Edith has grown beyond the age of attention-getting need. The individuality which she has found is one of a direct correlation between her heart and the natural forces of life. Her separateness is her responsibility for her own immortality. Her body is simply a husk given her to carry to the steps of salvation.

Her brightness of belief is all that matters, but still there is the cosmic anxiety that produced the later poetry. Almost in juxtaposition to "Song" we hear the sad refrain of "La Bella Bona Roba."

Alas, lass, lostAlas, lost.

$$
\text { (p. } 442)
$$

"La Bella Bona Roba" ends,

Young girl, you stare at me as if

I were that Medusa Time

That will change you, too, to stone:

So you, grown old, must lie alone.

Alas, lass, lost!

Alas...

(p. 443)

So death is still a thing to fear; it is still the unknown. All her years of poetic justification and rationalization could not convince her of nature's ultimate beneficence. 
But she does end her poetry on an optimistic note. The last lines of the Collected Poems states,

The small and great complete each other, and the end Leads to the beginning, and the beginning Leads to the end, Said the Man of Emeralds Dancing like a wave beneath the bough of Spring.

$$
(\mathrm{p} .447)
$$

Spring is rebirth. 
Brophy, James D. Edith Sitwe 11: The Symbolist Order. Carbondale: Southern Illino is Univ. Press, 1968.

Frazer, Sir James. The Golden Bough, 3rd ed. London: Macmilian and Co., 1925-1927.

Garcia Villa, Jose (ed.). A Celebration for Edith Sitwell. Norfolk, Connecticut: New Directions, 1948 .

Milis, Ralph J. Edith Sitwe11. Grand Rapids, Michigan: Erdmans, 1966.

Read, Herbert. Icon and Idea. New York: Schocken Books, 1965 .

Sitwel1, Edith. A Poet's Notebook. Boston: Little, Brown, 1950 .

- Collected Poems (new and enlarged ed.). New York: Vanguard Press, 1968.

- Taken Care Of. New York: A thenium, 1965.

Symons, Arthur. The Symbolist Movement in Literature.

New York: E.P. Button and Co., 1919.

Vickery, John B. "The Golden Bough and Modern Poetry." Journal of Aesthetics and Art Criticism, 15 (March 1957), 271-288. 